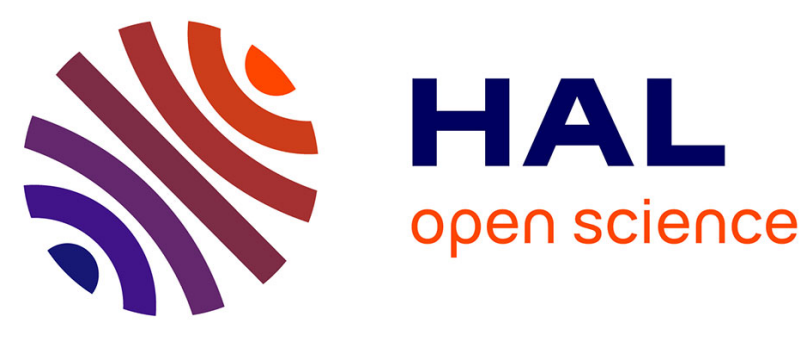

\title{
Rational synthesis and dimensionality tuning of MOFs from preorganized heterometallic molecular complexes
}

Aleksandr A. Sapianik, Mikhail A. Kiskin, Konstantin A. Kovalenko, Denis G. Samsonenko, Danil N. Dybtsev, Nathalie Audebrand, Yaguang Sun, Vladimir P. Fedin

\section{To cite this version:}

Aleksandr A. Sapianik, Mikhail A. Kiskin, Konstantin A. Kovalenko, Denis G. Samsonenko, Danil N. Dybtsev, et al.. Rational synthesis and dimensionality tuning of MOFs from preorganized heterometallic molecular complexes. Dalton Transactions, 2019, 48 (11), pp.3676-3686. 10.1039/c8dt05136d . hal-02086458

\section{HAL Id: hal-02086458 \\ https://hal-univ-rennes1.archives-ouvertes.fr/hal-02086458}

Submitted on 11 Apr 2019

HAL is a multi-disciplinary open access archive for the deposit and dissemination of scientific research documents, whether they are published or not. The documents may come from teaching and research institutions in France or abroad, or from public or private research centers.
L'archive ouverte pluridisciplinaire HAL, est destinée au dépôt et à la diffusion de documents scientifiques de niveau recherche, publiés ou non, émanant des établissements d'enseignement et de recherche français ou étrangers, des laboratoires publics ou privés. 


\title{
Rational synthesis and dimensionality tuning of MOFs from preorganized heterometallic molecular complexes
}

Received 00th January 20xx Accepted 00th January 20xx

DOI: $10.1039 / \times 0 x \times 00000 x$

www.rsc.org/

Aleksandr A. Sapianik, ${ }^{*}, \mathrm{a}, \mathrm{b}$ Mikhail A. Kiskin, ${ }^{\mathrm{c}}$ Konstantin A. Kovalenko, ${ }^{\mathrm{a}, \mathrm{b}}$ Denis G. Samsonenko, ${ }^{\mathrm{a}, \mathrm{b}}$ Danil N. Dybtsev, ${ }^{*}$ a,b Nathalie Audebrand, ${ }^{d}$ Yaguang Sun, ${ }^{e}$ and Vladimir P. Fedin ${ }^{a, b}$

\begin{abstract}
Rational design of a series of new heterometallic MOFs was carried out by the judicious choice of corresponding pivalate complexes $\left[\mathrm{Li}_{2} \mathrm{M}_{2}(\mathrm{piv})_{6}(\mathrm{py})_{2}\right]\left(\mathrm{M}=\mathrm{Zn}^{2+}, \mathrm{Co}^{2+}\right.$, piv- = pivalate anion and py = pyridine $)$ as a source of secondary building units, $\left\{\mathrm{LiM}\left(\mathrm{O}_{2} \mathrm{CR}\right)_{3}\right\}$ and organic tricarboxylate linker as a node defining the demensionality of the framework by the orientation of carboxylic group in or out of the central aromatic ring plane. Thus trimesate (btc ${ }^{3-}$ ) linker results in 3D srs topology frameworks with intersecting system or isolated channels, 1,3,5-benzenetribenzoate (btb ${ }^{3-}$ ) results in layered hcb isostructural compounds additionally stabilized with $\mathrm{H}-\pi$ interactions between layers. The layered compounds demonstrate a permanent porosity with BET surface area up to $688 \mathrm{~m}^{2} \cdot \mathrm{g}^{-1}$ with the possibility of selective gas adsorption $\left(\mathrm{CO}_{2}\right.$ over $\mathrm{N}_{2}$ and $\left.\mathrm{CH}_{4}\right)$. Zn-based coordination polymers show a notable color changes and drastic (up to 30 times) quenching of the luminescence upon inclusion of different nitroaromatics.
\end{abstract}

\section{Introduction}

Gas storage [1-6], separation [7-9], heterogeneous catalysis [10-11], chemical sensing [12-13], optoelectronics (ferroelectricity, non-linear optics, and LEDs) [14], drug delivery [15] - functional materials based on metal-organic frameworks (MOFs) find their places in each of these, as well as in many other areas. The most relevant and functionally important MOFs, such as HKUST-1 [16-17], IRMOFs [18-22], UiOs [23-24] and MILs [25-28], are based on polynuclear secondary building units (SBUs) self-assembled from metal ions at particular reaction conditions. In certain cases, these SBUs are known as discrete polynuclear complexes which provide possibility to facilitate the assembly of periodic coordination structures through a ligand exchange on those pre-organized complexes. This rationalizes the engineering of new compounds with predictable structures and suppresses the crystallization of impurities through competing selfassembly routes. More importantly, such approach could often be the only way to synthesize MOFs based on complex heterometallic SBUs where self-assembly route is very hard to

a. Nikolaev Institute of Inorganic Chemistry SB RAS, 3 Akad. Lavrentiev Av., 630090 Novosibirsk, Russia.

b. Novosibirsk State University, 2 Pirogova st., 630090 Novosibirsk, Russia.

c. N. S. Kurnakov Institute of General and Inorganic Chemistry, RAS, 31 Leninsky Av., 119991 Moscow, Russia.

d. Univ Rennes, CNRS, ISCR (Institut des Sciences Chimiques de Rennes) - UMR 6226, F-35000 Rennes, France.

e.Laboratory of Coordination Chemistry, Shenyang University of Chemical Technology, Shenyang 110142, People's Republic of China.

Electronic Supplementary Information (ESI) available: structural, PXRD, TGA, IR, luminescent data, sorption isotherms and IAST calculations, NMR spectra. See DOI: $10.1039 / x 0 x x 00000 x$ control and optimize [29]. Nevertheless, the ligand substitution on pre-organized SBUs is only demonstrated in a limited number of examples of synthesis of MOFs, therefore a further development of preparation methods of coordination polymers from pre-organized complexes is an important direction in the MOF area.

This work demonstrates the preparation of a series of porous coordination networks from tetranuclear complexes $\left[\mathrm{Li}_{2} \mathrm{M}_{2}(\text { piv })_{6}\right]\left(\mathrm{M}=\mathrm{Co}^{2+}, \mathrm{Zn}^{2+}\right.$; piv ${ }^{-}=$pivalate $)$which could be regarded as a dimer of two binuclear carboxylate units $\left\{\mathrm{LiM}(\mathrm{RCOO})_{3}\right\}$ with 3-connected nature. An extension of the $\left\{\mathrm{LiM}(\mathrm{RCOO})_{3}\right\}$ units through tricarboxylic ligands such as trimesate $\left(\mathrm{btc}^{3-}\right)$ or 1,3,5-benzenetribenzoate (btb $\left.{ }^{3-}\right)$ predictably leads to the formation of MOFs with 3-connected topologies. The obtained MOFs feature selective gas adsorption properties, luminescence quenching upon an inclusion of different nitroaromatic molecules as well as the separation of benzene/cyclohexane mixture in a liquid phase.

\section{Results and discussion}

\section{Material synthesis and structures.}

Tetranuclear coordination complex $\left[\mathrm{Li}_{2} \mathrm{Co}_{2}(\mathrm{piv})_{6}(\mathrm{py})_{2}\right]$ (1) was synthesized by a reaction of lithium pivalate salt Li(piv), polymeric amorphous $\left[\mathrm{Co}(\text { piv })_{2}\right]_{n}$ and pyridine in equimolar ratio in a mixture of $\mathrm{CH}_{3} \mathrm{CN}$ and THF. This synthetic methodic is similar to that for previously reported $\left[\mathrm{Li}_{2} \mathrm{M}_{2}(\text { piv })_{6}\right](\mathrm{M}=\mathrm{Ni}, \mathrm{Co}$, $\mathrm{Zn)}$ complexes [30-32].

The compound 1 crystallizes in triclinic space group $P-1$ (Fig. 1 ). The center of symmetry of the tetranuclear molecule is at the intersection of the diagonals of the almost square $\left[\mathrm{Li}_{2}\left(\mu_{2^{-}}\right.\right.$ 
O) 2 ] moiety (Figure 1), and the $\mathrm{Li}_{2} \mathrm{CO}_{2}$ core has a planar structure (Co...Li 3.098(5) $\AA$, Li...Li 2.665(9) $\AA$, Co-Li-Li $\left.121.8(3)^{\circ}\right)$.

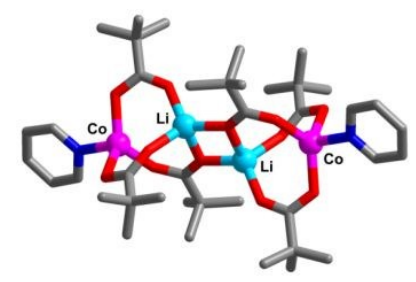

Figure 1. Molecular structure of $\left[\mathrm{Li}_{2} \mathrm{Co}_{2}(\text { piv })_{6}(\mathrm{py})_{2}\right]$.

Each $\mathrm{Co}^{2+}$ ion coordinates $\mathrm{N}$ atom of a pyridine ligand and three $\mathrm{O}$ atoms of three carboxylate groups (Co-N 2.067(2), Co-O 1.930(2)-1.952(2) Å), thus adopting a distorted tetrahedral coordination $\left(\mathrm{CoNO}_{3}\right)$. The coordination environment of the $\mathrm{Li}^{+}$ions $\left(\mathrm{LiO}_{4}\right)$ is tetrahedral ( $\mathrm{Li}-\mathrm{O}$ 1.889(5)-1.985(5) A). Three carboxylate bridges link the $\mathrm{Co}^{2+}$ and $\mathrm{Li}^{+}$ions with two carboxylates acting as bridges between two heterometallic centers, and one acting as a $\mu_{3}$-bidentate linker bridging two $\mathrm{Li}^{+}$ions through one $\mathrm{O}$ atom. The six carboxylate anions are directed perpendicularly to the Co- $\mathrm{Li}$ axis of the node, while $\mathrm{Co}-\mathrm{N}$ bonds are directed along this axis. In general complex is isostructural to previously reported $\left[\mathrm{Li}_{2} \mathrm{Zn}_{2}(\mathrm{piv})_{6}(\mathrm{py})_{2}\right]$ [32]. The only difference is that one $\mu_{2}$ bidentate oxygen atom in carboxylate group of pivalate anion connected to lithium cation. This atom is placed closer to Co cation forming weak interaction 2.590(7) $\AA$ unlike 2.749(2) $\AA$ in case of $\mathrm{Li}_{2} \mathrm{Zn}_{2}$ complex. Nevertheless such differences do not affect strongly on the overall similarity.

The tetranuclear complex $\left[\mathrm{Li}_{2} \mathrm{M}_{2}(\text { piv })_{6}\right]$ could be viewed as a dimer of 3-connecting dinuclear units $\left[\mathrm{LiM}(\text { piv })_{3}\right]$ fused via lateral $\mathrm{Li}-\mathrm{O}$ coordination interactions. The substitution of pivalate ligands to polycarboxylic ligands in such dinuclear units $\left[\mathrm{LiM}(\text { piv })_{3}\right]$ will result in a formation of 3 -connected coordination polymers based on the $\{\mathrm{LiM}\}$ nodes. It must be pointed out that the tricarboxylate dinuclear complexes $\left[\mathrm{M}_{2}\left(\mathrm{O}_{2} \mathrm{CR}\right)_{3}\right]$ are very rare, compared to the well-known and relatively abundant tetracarboxylate analogues $\left[\mathrm{M}_{2}\left(\mathrm{O}_{2} \mathrm{CR}\right)_{4}\right]$. Therefore, the $\left[\mathrm{Li}_{2} \mathrm{M}_{2} \text { (piv) }\right)_{6}$ complexes could be regarded as valuable source of heterometallic tricarboxylate dinuclear SBUs, previously observed only in a handful of MOF structures. The following nine MOFs are obtained from the $\left[\mathrm{Li}_{2} \mathrm{M}_{2}(\mathrm{piv})_{6}\right]$ $\left(\mathrm{M}=\mathrm{Co}^{2+}, \mathrm{Zn}^{2+}\right)$ and are solely based on such rare $\left[\mathrm{LiM}\left(\mathrm{O}_{2} \mathrm{CR}\right)_{3}\right]$ SBUs (Scheme 1).

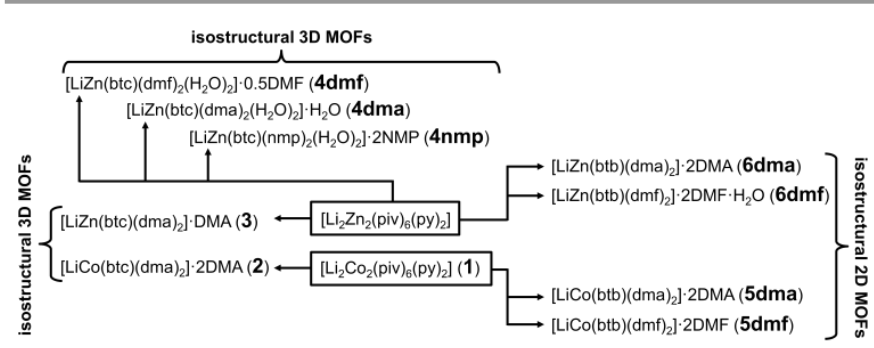

Scheme 1. General scheme of MOFs obtained from molecular complexes $\left[\mathrm{Li}_{2} \mathrm{M}_{2}(\text { piv })_{6}(\mathrm{py})_{2}\right](\mathrm{M}=\mathrm{Co}, \mathrm{Zn})$.
Compound [ $\left.\mathrm{LiCo}(\mathrm{btc})(\mathrm{dma})_{2}\right] \cdot 2 \mathrm{DMA}$ (2) was synthesized by a heating of 1 with 1,3,5-benzenetricarboxylic acid in DMA. 2 crystallizes in tetragonal chiral space group $P 4_{3} 2_{1} 2$. In the structure $\mathrm{Li}$ and $\mathrm{Co}$ atoms are in the same positions with $50 \%$ occupancy. Each Li/Co ion is bounded to the oxygen of DMA molecule and to three O-donors of three carboxylate groups, adopting a distorted tetrahedral coordination (Li/Co-O $1.916(2)-1.961(2) \AA ̊ A)$. Li and Co cations are connected by three bridging carboxylate groups forming a rare example of a tricarboxylate bimetallic paddle wheel fragment (Fig. 2). (a)

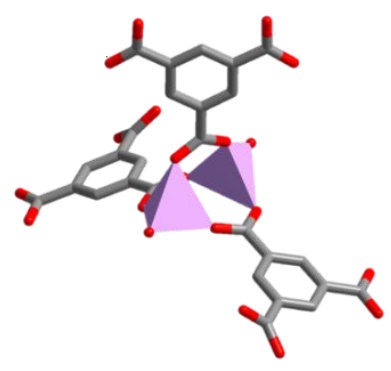

(b)

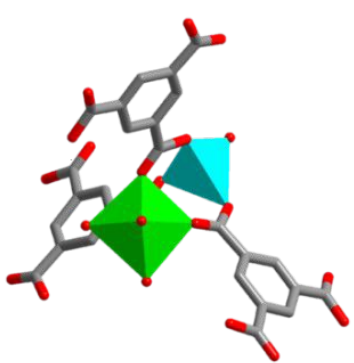

Figure 2. View of node in $\mathbf{2}$ and proposed for $\mathbf{4}$ (from left to the right). (hydrogen atoms are omitted; Li/Co cations are presented as lilac tetrahedra, $\mathrm{Li}-$ as cyan, $\mathrm{Zn}$ - as green).

These building blocks are connected with six others by benzenetricarboxylate linkers into 3D porous structure of chiral Si net in $\mathrm{SrSi}_{2}$ topology (srs) (Fig. 3a, S6). In a projection of the crystal structure perpendicular to $b$ axis one can identify a 1D channels about $7 \AA$ in diameter which are occupied by two coordinated and two guest DMA solvent molecules per formula unit (Fig. 3b). All solvent molecules were identified from the single-crystal X-ray diffraction data. The phase purity and chemical composition of $\mathbf{2}$ was confirmed by a number of methods and analyses, including AAS which supported the equimolar ratio for $\mathrm{Co}^{2+}$ and $\mathrm{Li}^{+}$ions for this heterometallic compound. It should be noted that the synthesis and structural investigation of the chiral antipode (enantiomer) of the compound 2 was published recently [33], however, the reported here X-ray crystallography data quality is much better, allowing the refinement of the DMA guest molecules in the channels.

The total accessible for solvent volume is $42 \%$ according to PLATON [34] calculated for structure without guest DMA molecules. The thermogravimetric (TG) data shows steady 54 $\%$ weight decrease upon heating to $400{ }^{\circ} \mathrm{C}$ corresponding to removal of all solvent molecules, followed by the framework decomposition (Fig. S16). 
(a)

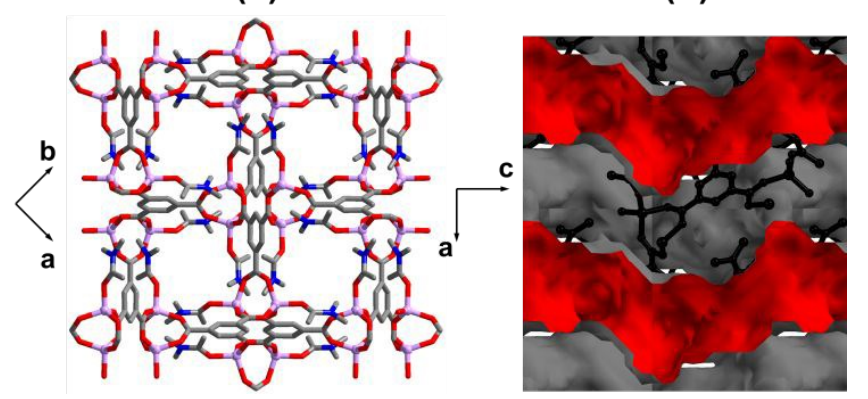

Figure 3. Structure projection of $\mathbf{2}$ perpendicular to $c(a)$ and $b(b)$ axis (the inner surface of channels is presented as red; Li/Co cations are presented as lilac balls).

Compound [LiZn(btc)(dma $\left.)_{2}\right] \cdot D M A ~(3)$ could be obtained in a solvothermal reaction of $\left[\mathrm{Li}_{2} \mathrm{Zn}_{2}(\text { piv })_{6}(\mathrm{py})_{2}\right]$ with $\mathrm{H}_{3}$ btc in DMA. Only a few crystals of the product were isolated as a minor impurity to the dominating phase $\mathbf{4 d m a}$ (see below). The compound $\mathbf{3}$ is totally isostructural to $\mathbf{2}$. Like in previous case, both $\mathrm{Li}(\mathrm{I})$ and $\mathrm{Zn}(\mathrm{II})$ cations are disordered over two positions with $50 \%$ occupancy, thus they have similar coordination geometry. Each $\mathrm{Li} / \mathrm{Zn}$ cation is bounded to the oxygen atom of DMA molecule and to three O-donors of three carboxylate groups, thus adopting a distorted tetrahedral coordination (Li/Zn-O 1.897(3)-1.989(2) Å). The total accessible for solvent volume is $42 \%$.

The heating of $\left[\mathrm{Li}_{2} \mathrm{Zn}_{2}(\text { piv })_{6}(\mathrm{py})_{2}\right]$ complex with benzenetricarboxylic acid in either DMF, DMA or NMP resulted in a precipitation of the compounds $\left[\mathrm{LiZn}(\mathrm{btc})(\mathrm{dmf})_{2}\left(\mathrm{H}_{2} \mathrm{O}\right)_{2}\right] \cdot 0.5 \mathrm{DMF}$

$\left[\mathrm{LiZn}(\mathrm{btc})(\mathrm{dma})_{2}\left(\mathrm{H}_{2} \mathrm{O}\right)_{2}\right] \cdot \mathrm{H}_{2} \mathrm{O}$

(4dma),

(4dmf),

[LiZn(btc) (nmp) $\left.\left(\mathrm{H}_{2} \mathrm{O}\right)_{2}\right] \cdot 2 \mathrm{NMP}(\mathbf{4 n m p})$. Note, that the heating of a very similar $\left[\mathrm{Li}_{2} \mathrm{Co}_{2}(\text { piv })_{6}(\mathrm{py})_{2}\right]$ (1) produces $\mathbf{2}$ in DMA, while the other media (DMF, NMP) affords only amorphous phases. We were not able to identify structures 4 by the single-crystal X-ray diffraction method, but the powder X-ray data clearly suggested that all compounds $\mathbf{4}$ are isostructural to the known MOFs $\left[\mathrm{Zn}_{2}(\mathrm{btc})\left(\mathrm{H}_{2} \mathrm{O}\right)\left(\mathrm{C}_{2} \mathrm{H}_{5} \mathrm{OH}\right)_{2}\left(\mathrm{NO}_{3}\right)\right]$ [35] or $\left[\mathrm{CoZn}(\mathrm{btc})(\mathrm{dmf})_{3}\left(\mathrm{NO}_{3}\right)\right]$ [36]. The Le Bail fit was carried out to identify the space group and to calculate the unit cell parameters from the PXRD data (Fig. S13-15). For $\mathbf{4 d m f}$ found unit cell is $P 2_{1} 3 / \mathrm{a}=14.356(2) \AA ; 4 \mathrm{dma}-P 2_{1} 3 / \mathrm{a}=14.338(3)$ $\AA$; $4 \mathrm{nmp}-P 2_{1} 3 / \mathrm{a}=14.494$ (4) $\AA$ which is very close to both $\left[\mathrm{Zn}_{2}(\mathrm{btc})\left(\mathrm{H}_{2} \mathrm{O}\right)\left(\mathrm{C}_{2} \mathrm{H}_{5} \mathrm{OH}\right)_{2}\left(\mathrm{NO}_{3}\right)\right]-P 2_{1} 3 / \mathrm{a}=14.728(4) \AA$ and $\left[\mathrm{CoZn}(\mathrm{btc})(\mathrm{dmf})_{3}\left(\mathrm{NO}_{3}\right)\right]-P 2_{1} 3 / \mathrm{a}=14.1520$ (3) $\AA$. In the known compound $\left[\mathrm{CoZn}(\mathrm{btc})(\mathrm{dmf})_{3}\left(\mathrm{NO}_{3}\right)\right]$ tetrahedral $\mathrm{Zn}(\mathrm{II})$ ion is filled by a nitrate to maintain charge neutrality, while the $\mathrm{Co}$ (II) is in octahedral environment due to the coordination of three solvent molecules. Taking into account the literature data as well as the chemical analyses including AAS spectrometry to determine $\mathrm{Li}$ and $\mathrm{Zn}$ concentration, the compounds $\mathbf{4}$ are supposedly built from the dinuclear heterometallic $\left\{\mathrm{LiZn}(\mathrm{RCOO})_{3}\right\}$ tricarboxylate units, already seen in 3 . The $\mathrm{Li}^{+}$ cations are coordinated by four atoms: three carboxylate oxygens and one solvent molecule. The coordination environment of $\mathrm{Zn}^{2+}$ in $\mathbf{4}$ is believed to be octahedral with tree carboxylate anions, one solvent molecule and two $\mathrm{H}_{2} \mathrm{O}$ molecules according to microelemental analysis. The dinuclear tricarboxylate SBUs $\left\{\mathrm{LiZn}(\mathrm{RCOO})_{3}\right\}$ are then supposedly connected by trimesate anions into 3-connected network with srs topology, similar to that in $\mathbf{2}$ or $\mathbf{3}$. Assuming the structural similarity to the known compounds, the pore system in $\mathbf{4}$ should contain a 3-D structure with nearly $44 \%$ of the framework represented by an extended channel system having a $14 \AA$ cross-section filled with coordinated and free solvent molecules [35]. The final formulas for the series of isostructural compounds (Fig. 4c) 4 were established on the basis of chemical analysis as well as TG data. According to TG analyses, the $\mathbf{4 d m f}$ loses $44 \%$ of weight with removal of all solvent molecules upon heating up to $400^{\circ} \mathrm{C}(43.9 \%$ calculated from empirical formula), $4 \mathrm{dma}$ TG weight loss is $43.2 \%$ ( $45 \%$ calculated from empirical formula) and $\mathbf{4 n m p}$ TG weight loss is $60.4 \%$ (60.8\% from empirical formula) (Fig. S16).

The obtained crystalline MOFs 2-4 with demonstrated srs network topology are isoreticular to previously known series of homo- and heterometallic trimesates $\left[\mathrm{MM}^{\prime}(\mathrm{btc})\right](\mathrm{An})$, where $\mathrm{M}, \mathrm{M}^{\prime}=\mathrm{Zn}^{2+}, \mathrm{Co}^{2+}, \mathrm{Ni}^{2+}, \mathrm{An}=$ anion [35-38]. The main difference is that the frameworks 2-4 are charge-neutral in contrast with the cationic ones reported in the literature. This should be considered as a potential advantage since the absence of any counter-ions expands the guest accessible volume for a porous structure. (a)

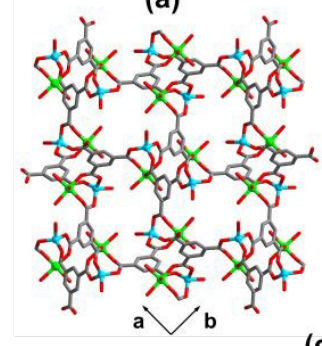

(b)

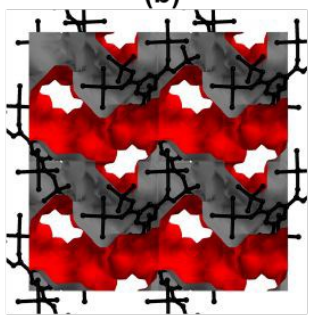

c)

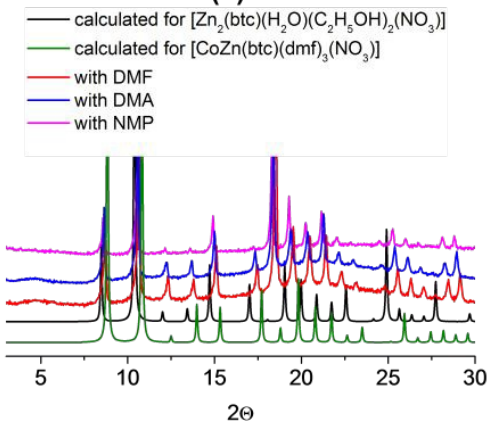

Figure 4. Proposed structure projection of $\mathbf{4}$ perpendicular to $c$ axis $(a, b)$ (Li cations are presented as blue balls, $\mathrm{Zn}$ - as green; calculated pore surface is presented as red $-b$ ). Comparison of PXRD data for known trimesates $\left[\mathrm{Zn}_{2}(\mathrm{btc})\left(\mathrm{H}_{2} \mathrm{O}\right)\left(\mathrm{C}_{2} \mathrm{H}_{5} \mathrm{OH}\right)_{2}\left(\mathrm{NO}_{3}\right)\right]$ [35] or $\left[\mathrm{CoZn}(\mathrm{btc})(\mathrm{dmf})_{3}\left(\mathrm{NO}_{3}\right)\right][36]$ and for 4 compounds $(c)$.

Single crystals of $\left[\mathrm{LiCo}(\mathrm{btb})(\mathrm{dma})_{2}\right] \cdot \mathrm{DMA} \quad(\mathbf{5} \mathbf{d m a})$ and $\left[\mathrm{LiZn}(\mathrm{btb})(\mathrm{dmf})_{2}\right] \cdot 2 \mathrm{DMF} \cdot \mathrm{H}_{2} \mathrm{O} \quad(\mathbf{6 d m f})$ were synthesized by heating of $\left[\mathrm{Li}_{2} \mathrm{M}_{2}(\text { piv })_{6}(\mathrm{py})_{2}\right] \quad(\mathrm{M}=\mathrm{Co}, \mathrm{Zn})$ complexes, respectively, with 1,3,5-tris(4-carboxyphenyl)benzene $\left(\mathrm{H}_{3} \mathrm{btb}\right)$ in either $\mathrm{DMA} / \mathrm{CH}_{3} \mathrm{CN}$ or $\mathrm{DMF} / \mathrm{CH}_{3} \mathrm{CN}$. All these compounds appear to be isostructural as evidenced by powder X-ray diffraction data (Figs. S9, S10). 5dma crystallizes in monoclinic 
space group 12/a. In this structure $\mathrm{Li}$ and Co cations are disordering over two positions with $50 \%$ occupancy, similarly to 2 and 3. Each $\mathrm{Li} / \mathrm{Co}$ ion coordinates the $\mathrm{O}$ atom of DMA molecule and three $\mathrm{O}$ atoms of three carboxylate groups, thus adopting a distorted tetrahedral coordination (Li/Co-O 1.900(2)-2.016(3) Å) (Fig. 5).
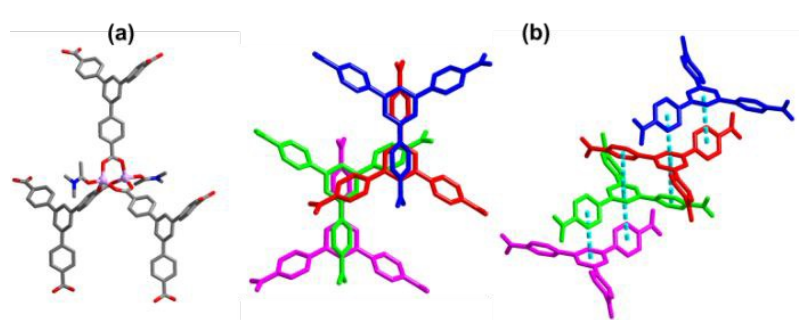

Figure 5. View of node in $\mathbf{5} \mathbf{d m a}(a)$; hydrogen atoms are omitted; Li/Co cations are presented as lilac balls. Stabilizing interactions between benzene rings of the btb-linker of four independent layers of $\mathbf{5} \mathbf{d m a}$ in different projections $(b)$. Short contacts are shown as cyan dashed lines.

The $\{$ CoLi\} dinuclear tricarboxylate moieties are connected by benzenetribenzoate $\left(\mathrm{btb}^{3-}\right)$ linkers into a 3-connected layered network with honeycomb topology hcb. Four independent layers are stacked atop each other with slight shift forming a 4periodic $A B C D$ packing (Fig. 6). The packing of the layer is stabilized by weak $\mathrm{C}-\mathrm{H} \cdots \pi$ interactions between benzene rings of btb $^{3-}$ linkers of alternating layers (Fig. $5 \mathrm{~b}$ ). In a projection of the crystal packing perpendicular to the $c$ axis, a 1D channels about $6 \AA$ in diameter, occupied by highly disordered solvent molecules could be identified. The PLATON/SQUEEZE procedure allowed us to calculate the contribution to the diffraction from the solvent region and produced a set of solvent-free diffraction intensities [39]. The final formula of 5dma, [LiCo(btb)(dma $\left.)_{2}\right] \cdot 2 \mathrm{DMA}$, was derived from the SQUEEZE results (188e per unit cell - one DMA guest molecule per formula unit) which is in acceptable agreement with elemental and thermogravimetric analyses (which gives 2 guest DMA molecules per formula unit). The solvent volume of the channels was calculated to be $25.8 \%$. The TGA data shows steady $39 \%$ weight decrease upon heating to $400{ }^{\circ} \mathrm{C}$ corresponding to removal of all solvent molecules $(40.9 \%$ calculated from empirical formula), followed by the framework decomposition (Fig. S16).

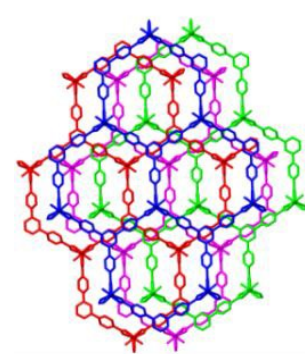

(a)

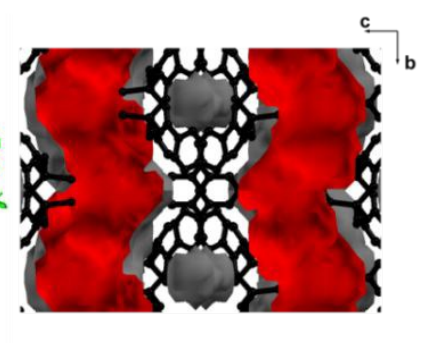

(b)
Figure 6. Independent layers in $\mathbf{5}(a)$, and channels view perpendicular to a axis $(b)$.

Except for the difference in the solvent molecules, $6 \mathrm{dmf}$ is isostructural to $\mathbf{5 d m a}$. Consequently, $\mathbf{6} \mathbf{d m f}$ is based on the bimetallic tricarboxylate paddlewheel $\{\mathrm{LiZn}\}$ unit both $\mathrm{Li}$ and $\mathrm{Zn}$ cations merged between two positions. The $\mathrm{Li} / \mathrm{Zn}-\mathrm{O}$ metalligand distances are in the range 1.898(3)-2.016(3) $\AA$. The overall crystal structure 6 is formed by stacking of honeycomb layers (hcb) with the system of channels almost identical to that in $\mathbf{5}$ (Fig. S5). The final formula of $\mathbf{6} \mathbf{d m f}$ was derived from the SQUEEZE results (168e per unit cell) with elemental analysis and TGA ( 2 guest DMF and one guest water molecule per formula unit). The thermogravimetric data shows steady $41 \%$ weight decrease upon heating to $400{ }^{\circ} \mathrm{C}$ corresponding to removal of both guest and coordinated solvent molecules (37.9\% calculated from empirical formula), followed by the framework decomposition (Fig. S16). Similar compounds $\mathbf{5 d m f}$ and $\mathbf{6 d m a}$ could be also precipitated from the corresponding solvents. According to the PXRD data these are fully isostructural to $\mathbf{5 d m a}$ and/or $\mathbf{6 d m f}$ (Fig. S9, S10).

It should be noted that all the reported compounds 2-6 were prepared from the complexes $\left[\mathrm{Li}_{2} \mathrm{M}_{2}(\text { piv })_{6}\right]$, which tetranuclear core is composed of two fused dinuclear units $\left\{\mathrm{LiM}(\mathrm{piv})_{3}\right\}$ via lateral $\mathrm{Li}-\mathrm{O}$ coordination interactions. In previous examples we showed the preservation of the tetranuclear core during the MOF assembly through linear ditopic ligands $[32,40]$. Apparently, the polycondensation in the presence of 3connected carboxylic ligands facilitates the dichotomy of the tetranuclear complex to dinuclear units and the formation of either 2D or 3D 3-conencted coordination networks, or only presence of $\mathrm{N}$-donor ditopic ligands can stabilize the tetranuclear core [40]. Remarkably, the honeycomb (hcb) and $\mathrm{SrSi}_{2}$ (srs) nets are the most regular topologies among the $2 \mathrm{D}$ or 3D 3-connected nets, respectively [41]. Such regular nets are especially interesting and important for the crystal engineering since self-assembly of periodic structures usually follows the most symmetrical and simple way. For example, diamond net and primitive cubic net are the overwhelmingly dominating topologies among known 3D structures, being the most regular network types for 4- and 6-connecting nets, respectively [42].

Interestingly, the key factor in dimensionality of the coordination networks in the obtained products lies in the geometry and flexibility of the organic ligand (Scheme 2).

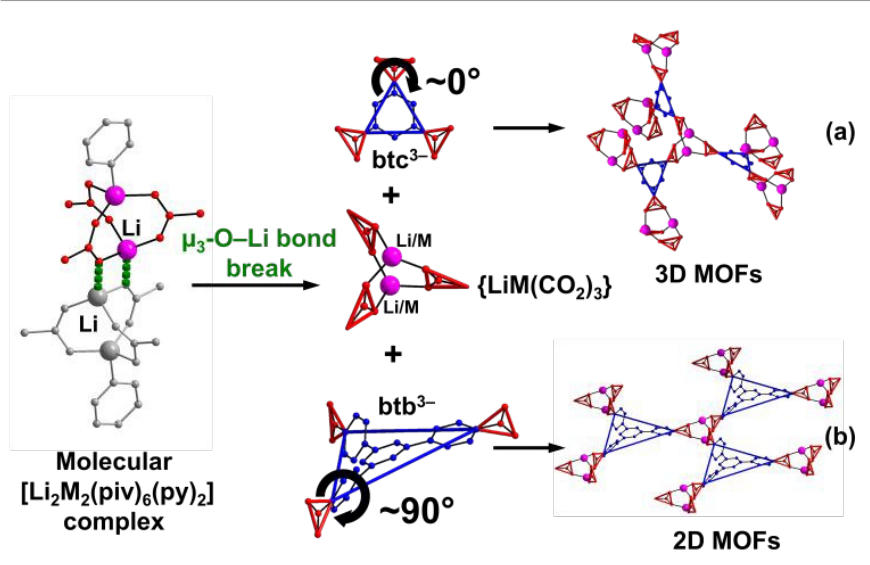

Scheme 2. General representation of $\{\mathrm{LiM}\}$ building block formation and construction of coordination polymers with different dimentionality depending on the position of carboxylic group in plane of the ligand (a) forming a 3D framework or out of the plane (b) forming hcb layered structure. 
Indeed, a rather rigid structure of the tricarboxylate unit $\left\{\operatorname{LiM}\left(\mathrm{O}_{2} \mathrm{CR}\right)_{3}\right\}$ fixes the planes of the carboxylate groups along the LiM axis, which is perpendicular to the plane of this 3connected node. The planar 2D honeycomb net could only be assembled if the organic ligand allows the same orientation of the carboxylate groups, perpendicular to the plane of the organic ligand itself. The aromatic rings of the $\mathrm{btb}^{3-}$ anion are known to be tilted due to $\mathrm{H} \cdots \mathrm{H}$ repulsion while the trimesate $\left(b^{3-}\right)$ anion is almost perfectly planar with all three carboxylate groups lying in the same plane. Therefore, the connection of $\left\{\operatorname{LiM}\left(\mathrm{O}_{2} \mathrm{CR}\right)_{3}\right\}$ units through btc ${ }^{3-}$ necessarily directs the alignment of the 3-connected nodes out of the plane forming a 3D structure. Contrary, more flexible btb ${ }^{3-}$ anion allows the same orientation of $\left\{\mathrm{LiM}\left(\mathrm{O}_{2} \mathrm{CR}\right)_{3}\right\}$ units within the plane; thus, the formation of honeycomb 2D layers becomes possible. Therefore, the crystallization of 2D hcb or $3 D$ srs 3 -conencted nets by the reaction of $\left[\mathrm{Li}_{2} \mathrm{M}_{2}(\mathrm{piv})_{6}\right]$ complexes with $\mathrm{btb}^{3-}$ or $\mathrm{btc}^{3-}$ ligands, respectively, is to be expected. Even though we did not anticipate the outcome, the above-mentioned retro-synthetic analysis of the results rationalizes the underlying relations between the reaction conditions and the crystal structure of the products. The synthesis of the compounds 2-6 represents an example of a successful design of coordination polymers with regular 3connected topologies based on rare tricarboxylate secondary building blocks.

\section{Gas adsorption and selectivity}

As far as $\mathbf{2}$ demonstrates low stability upon the guest removal (Figure S7) and no gas adsorption the compound

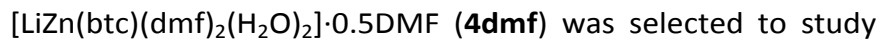
gas adsorption properties of isoreticular $43 \mathrm{D}$ nets with srs topology. The liquid-phase replacement of DMF solvent molecules with volatile acetone, followed by a low-pressure activation at $80^{\circ} \mathrm{C}$ was carried out. Despite relatively mild activation conditions, the powder XRD data (Fig. S8) indicate amorphization of the porous material. Accordingly, the remaining solid demonstrates poor $\mathrm{CO}_{2}$ adsorption $c a .40$ $\mathrm{mL} \cdot \mathrm{g}^{-1}$ at $1 \mathrm{bar}, 195 \mathrm{~K}$, which is an order of magnitude lower than the expected value.

The gas adsorption properties of isostructural 2D MOFs with hcb topology were also investigated. Despite their layered nature these compounds turned out to be stable upon the guest molecules removal (Figure S12). The characterization of texture and porosity of the activated material $\left[\mathrm{LiCo}(\mathrm{btb})(\mathrm{dmf})_{2}\right]$ $\mathbf{5 d m f}$ was carried out by measurements of $\mathrm{N}_{2}$ and $\mathrm{CO}_{2}$ adsorption isotherms at $77 \mathrm{~K}$ and $195 \mathrm{~K}$, respectively. Although the observed nitrogen adsorption was quite low $(19.4 \mathrm{~mL} / \mathrm{g})$ the $\mathrm{CO}_{2}$ capacity was rather reasonable reaching $106 \mathrm{~mL} / \mathrm{g}$ (Figure 7a). The measured pore volume is $0.153 \mathrm{~cm}^{3} \cdot \mathrm{g}^{-1}$, which is in a good agreement with the calculated porosity of the framework $\mathbf{5 d m f}$ based on the structural data, assuming the complete removal of guest DMF molecules. Similarly, the porosity of the activated $\mathbf{5 d m a}$ and $\mathbf{6 d m f}$ was also characterized (Table 2, Figure S19). We tried to find out the nature of such selective $\mathrm{CO}_{2}$ adsorption. Some indirect conclusions could be drawn from the careful analysis of the pore surfaces in the structures $\mathbf{5} \mathbf{d m a}$ and $\mathbf{6} \mathbf{d m f}$ (all compounds 5 and 6 are isostructural but have different coordinated solvent molecules). As could be seen in the projection of the structures along the channels (Figure S5), a coordinated DMF (left) or DMA (right) molecules could clearly be identified on the surface of the channel. Such geometry potentially allows the intermolecular interactions between the $\mathrm{CO}_{2}$ molecules and the coordinated solvent (DMF, DMA) molecules.

Table 2 Calculated parameters of porous structure for activated 5 and 6 compounds for different gases and temperatures.

\begin{tabular}{|c|c|c|c|c|c|c|c|}
\hline \multirow{2}{*}{ № } & \multirow{2}{*}{ Gas@T } & \multicolumn{3}{|c|}{ Specific surface area $\mathrm{m}^{2} \cdot \mathrm{g}^{-1}$} & \multicolumn{2}{|c|}{$V_{\text {pore }} / \mathrm{cm}^{3} \cdot \mathrm{g}^{-1}$} & \multirow{2}{*}{$\begin{array}{c}V_{a d s}{ }^{a} / \\
c^{3}(S T P) . \\
g^{-1}\end{array}$} \\
\hline & & Langmuir & BET & DFT & Total $^{a}$ & $\mathrm{DFT}^{b}$ & \\
\hline \multirow{2}{*}{$5 \mathrm{dma}$} & $\mathrm{N}_{2} @ 77 \mathrm{~K}$ & $--^{c}$ & 4.8 & $-c$ & $--^{c}$ & $-^{c}$ & 4.5 \\
\hline & $\mathrm{CO}_{2} @ 195 \mathrm{~K}$ & 509.9 & 426.3 & 224.6 & 0.230 & 0.157 & 108.6 \\
\hline \multirow{2}{*}{$5 \mathrm{dmf}$} & $\mathrm{N}_{2} @ 77 \mathrm{~K}$ & 69.5 & 63.4 & 62.2 & 0.030 & 0.028 & 19.4 \\
\hline & $\mathrm{CO}_{2} @ 195 \mathrm{~K}$ & 509.1 & 419.4 & 224.3 & 0.224 & 0.153 & 106.0 \\
\hline $5 \mathrm{dmf}^{d}$ & $\mathrm{CO}_{2} @ 195 \mathrm{~K}$ & 318.4 & 265.7 & 143.2 & 0.157 & 0.107 & 74.0 \\
\hline \multirow{2}{*}{$6 \mathrm{dmf}$} & $\mathrm{N}_{2} @ 77 \mathrm{~K}$ & 125.3 & 116.9 & 133.3 & 0.071 & 0.075 & 45.6 \\
\hline & $\mathrm{CO}_{2} @ 195 \mathrm{~K}$ & 768.5 & 687.7 & 820.3 & 0.394 & 0.251 & 185.1 \\
\hline measu & $\mathrm{P} / \mathrm{P}_{0}=0$, & & & & & & \\
\hline
\end{tabular}

The calculated BET surface areas were found to be 419,426 and $688 \mathrm{~m}^{2} / \mathrm{g}$ for the activated compounds $\mathbf{5} \mathbf{d m f}, \mathbf{5 d m a}$ and $\mathbf{6 d m f}$, respectively. Attempts of the activation of $\mathbf{5 d m f}$ at higher temperature in order to remove the coordinated DMF solvent only led to the gradual decomposition of the porous structure as evidenced by the decrease of the gas adsorption properties and PXRD data (Figure 7a, Figure S12).

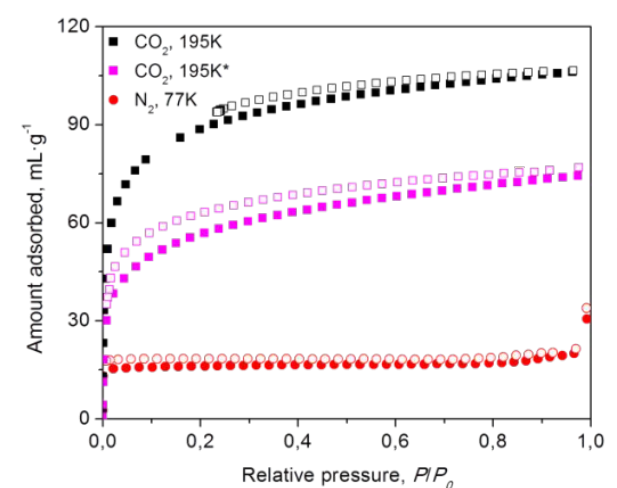

(a)

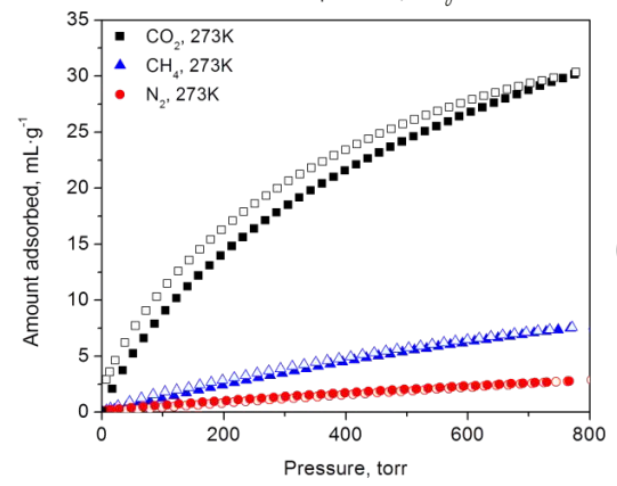

(b)

Figure 7. Adsorption-desorption isotherms of $\mathrm{N}_{2}$ at $77 \mathrm{~K}$ and $\mathrm{CO}_{2}$ at $195 \mathrm{~K}$ by activated $5 \mathbf{d m f}\left(\mathrm{a},{ }^{*}\right.$ - sample was additionally evacuated at $393 \mathrm{~K}$ for 4 hours). Adsorption-desorption isotherms of $\mathrm{CO}_{2}, \mathrm{CH}_{4}$ and $\mathrm{N}_{2}$ at $273 \mathrm{~K}$ by activated $6 \mathrm{dmf}(\mathrm{b})$.

The activated $\mathbf{5 d m f}$ was selected as prototype of the title layered compounds for the detailed gas adsorption measurements and selectivity calculations. The adsorption 
isotherms of $\mathrm{N}_{2}, \mathrm{CH}_{4}$ and $\mathrm{CO}_{2}$ was measured at $273 \mathrm{~K}$ (Figure 7b) and $298 \mathrm{~K}$ (Figure S20, Table S1). The selectivity factors (SF) of the adsorption of $\mathrm{CO}_{2}$ over either $\mathrm{N}_{2}$ or $\mathrm{CH}_{4}$ were estimated by three commonly used methods (see ESI): i) as a ratio of adsorbed volumes; ii) as a ratio of Henry's constants; iii) by ideal adsorbed solution theory (IAST). Table 3 shows the results of the selectivity factors calculations for $\mathbf{5 d m f}$ at $273 \mathrm{~K}$ for equimolar gas mixture. The compound demonstrates moderate selectivity in case of $\mathrm{CO}_{2} / \mathrm{CH}_{4}$ (Table 3 at $273 \mathrm{~K}$, Table S5 at $298 \mathrm{~K}$ ) and rather high selectivity in case of $\mathrm{CO}_{2} / \mathrm{N}_{2}$ gas mixtures. According to IAST, the highest $S F$ values were $S F$ $=8.3$ and 70.5 for $\mathrm{CO}_{2} / \mathrm{CH}_{4}$ and $\mathrm{CO}_{2} / \mathrm{N}_{2}$ equimolar gas mixtures, respectively. Also, the IAST calculations (see ESI) allowed us to obtain the selectivity factors as a function of the gas mixture compositions or the absolute pressure for $\mathrm{CO}_{2} / \mathrm{N}_{2}$ gas mixture at $273 \mathrm{~K}$ (Figure S21) as well as for $\mathrm{CO}_{2} / \mathrm{CH}_{4}$ mixture at both $273 \mathrm{~K}$ and $298 \mathrm{~K}$ (Figure S22). These data demonstrate a good potential of the obtained layered MOF compounds for the gas separation applications.

Table $\mathbf{3}$ Calculated adsorption selectivity factors on $\mathbf{5} \mathbf{d m f}$ for equimolar binary gas mixtures at $273 \mathrm{~K}$.

\begin{tabular}{cccc}
\hline & & & \\
\hline Gas mixture & $\boldsymbol{V}_{2} / \boldsymbol{V}_{\mathbf{1}}$ & $\boldsymbol{K}_{\boldsymbol{h} 2} / \boldsymbol{K}_{\boldsymbol{h 1}}$ & IAST \\
\hline $\mathrm{CO}_{2} / \mathrm{N}_{2}$ & 10.9 & 31.4 & 70.5 \\
$\mathrm{CO}_{2} / \mathrm{CH}_{4}$ & 4.0 & 9.5 & 8.3 \\
\hline
\end{tabular}

\section{Benzene/cyclohexane separation}

Cyclohexane is a valuable chemical utilized in synthesis of polymers. It is obtained exclusively by a hydrogenation of benzene. The effective cyclohexane/benzene separation is one of the most important industrial processes to be optimized since a conventional vapor fractional separation is hampered by a similarity of the boiling points of these compounds [43]. A great potential of porous MOFs for the cyclohexane/benzene separation has been already demonstrated a number of times [44-46]. The small aperture of channels in 6, lined with aromatic functionalities can facilitate benzene extraction from the benzene/cyclohexane mixtures due to possible $\pi-\pi$ stacking interactions. The as synthesized $\mathbf{6} \mathbf{d m f}$ was immersed into the equimolar benzene/cyclohexane mixture at room temperature for $24 \mathrm{~h}$. After that the crystalline phase was filtered and treated with DMF for $24 \mathrm{~h}$ to extract the solvent molecules. The ${ }^{1} \mathrm{H}$ NMR data showed that the composition of desorbed benzene/cyclohexane mixture was 3:1 in favor of the aromatic benzene, supporting our idea (Figure S23). Total amount of adsorbed benzene corresponds to nearly 1 benzene molecule per formula unit.

\section{Guest-Exchange and Photoluminescence Studies.}

Due to the benzenetricarboxylate and benzenetribenzoate aromatic ligands, the title frameworks $\mathbf{4} \mathbf{d m f}$ and $\mathbf{6} \mathbf{d m f}$ exhibit photoluminescent $(\mathrm{PL})$ properties. The dependence of such properties upon the presence of a certain guest molecules in the channels of porous MOFs have been exploited in sensor applications a number of times already $[12,47]$. In this work porous $\mathbf{4 d m f}$ and $\mathbf{6 d m f}$ were selected to investigate their guest-dependent luminescence towards various nitroaromatic molecules, such as nitrobenzene (NB), 4-nitro-m-xylene (NX) and 2,6-dimethylnitrobenzene (DMNB). The guest (solvent) molecules were substituted by immersing of the assynthesized crystals into a nitroaromatic compound for 2 days. According to powder XRD data, the crystals $\mathbf{4 d m f}$ appeared to be unstable in NX and DMNB and moderately stable in NB (Figure S8) while $\mathbf{6 d m f}$ is stable in all three aromatic solvents (Figure S11). The superior stability of layered hcb compound 6dmf over 3D srs framework $4 \mathbf{d m f}$ supports the observations during the gas adsorption measurements.

The PL spectra of the as-synthesized $\mathbf{4} \mathbf{d m f}$ has maximum emission at $\lambda_{\text {em }}=370 \mathrm{~nm}\left(\lambda_{\text {ex }}=300 \mathrm{~nm}\right.$, Fig. S24) with rather low quantum yield $\varphi \approx 1 \%$. Because of complete electron shell configurations of both $\mathrm{Zn}^{2+}$ and $\mathrm{Li}^{+}$, the observed emission should apparently be attributed to the intraligand $\pi^{*} \rightarrow \pi$ electron transfer of the btc $^{3-}$ anion, similar to the other reported examples [48-51]. The inclusion of the nitrobenzene shifts the emission maximum to $\lambda_{\mathrm{em}}=490 \mathrm{~nm}$ and significantly reduces the luminescence of $\mathbf{4 d m f} \cdot \mathbf{N B}$ about 18 times. Such luminescence quenching is usually attributed to a chargetransfer mechanism from the excited btc $^{3-}$ ligands to the electron-deficient aromatic system of guest NB [12, 40, 52].

The PL spectra of the as-synthesized $\mathbf{6} \mathbf{d m f}$ has maximum emission at $\lambda_{\mathrm{em}}=350 \mathrm{~nm}\left(\lambda_{\mathrm{ex}}=300 \mathrm{~nm}\right.$, Fig. 9), similarly to known examples [53]. Like in previous case, the PL mechanism should be assigned solely to the intraligand $\pi^{*} \rightarrow \pi$ transition in the $b b^{3-}$ anion. Due to the polyaromatic nature of the organic ligand, the emission of $\mathbf{6 d m f}$ is far more intense and efficient than in $\mathbf{4 d m f}$, with $\varphi \approx 30 \%$. The substitution of solvent DMF to either NB, NX or DMNB results in a reduction of the luminescence intensity. The spectra of the PL emission of the guest-exchanged samples $\mathbf{6 d m f \cdot G}$ feature bathochromic shift of the maxima $\left(\lambda_{\mathrm{em}}=515-540 \mathrm{~nm}\right)$. Such UV-induced color changes clearly visualize the presence of the nitroaromatic species (Fig. 8). The guest-dependent luminescence demonstrated here for $\mathbf{4} \mathbf{d m f}$ and $\mathbf{6} \mathbf{d m f}$ is an important demonstration of the principle of a detection of different nitroaromatic species.

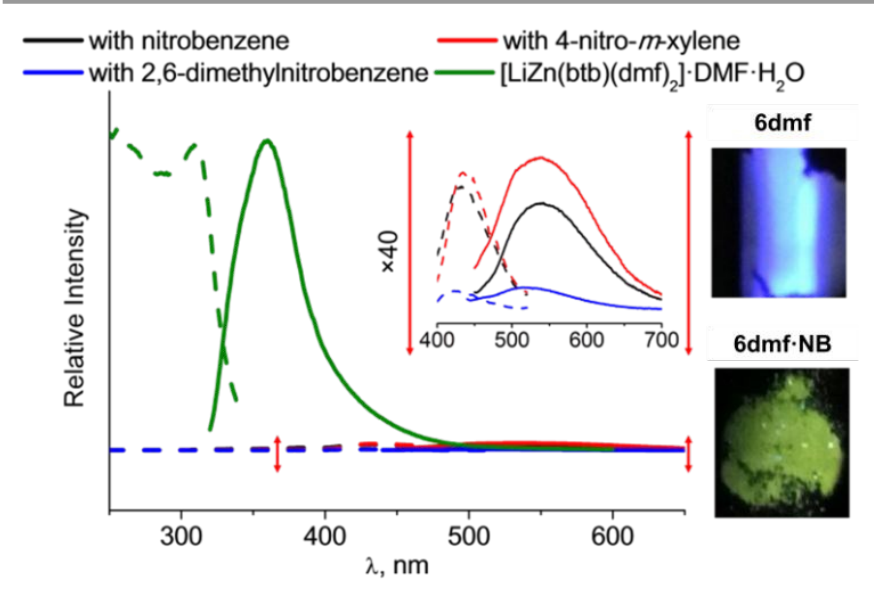

Figure 8. Spectra of emission (solid) and excitation (dashed) of $6 \mathbf{d m f}$ and inclusion compounds $\left(\lambda_{\mathrm{Ex}}=300 \mathrm{~nm}\right.$, spectral slit width $=1.8 \mathrm{~mm}$ for $6 \mathrm{dmf} ; 420 \mathrm{~nm}, 5 \mathrm{~mm}$ for guest-exchanged samples). Microphotographs of luminescent species of $6 \mathbf{d m f}$ as synthesized and $\mathbf{6 d m f} \cdot \mathbf{N B}$. 


\section{Experimental}

Materials and Methods.

Commercial reagents (pyridine $(>99 \%)$ ) and solvents (acetonitrile (99\%), tetrahydrofuran (THF, 99.9\%)) were used without additional purification. The starting complexes $\left[\mathrm{Co}(\text { piv })_{2}\right]_{n}$ and Li(piv) were synthesized according to procedures described previously [54,55]. The attenuated total reflection infrared (ATR-IR) spectra of 1 were recorded in the range $4000-400 \mathrm{~cm}^{-1}$ on a Perkin Elmer Spectrum 65 instrument. Elemental analysis of $\mathbf{1}$ was carried out with a Carlo Erba automatic C,H,N,S-analyzer. Unless specified, all reagents for synthesis of 2-6 were obtained from commercial sources and were used as received. Solvents acetone (99.99\%), $\mathrm{N}, \mathrm{N}$-dimethylacetamide (DMA, 99\%) and $\mathrm{N}$-methyl-2pyrrolidone (NMP, 99\%) were used without additional purification. $\mathrm{N}, \mathrm{N}$-dimethylformamide (DMF, 99\%) was treated over activated molecular sieves $3 \AA$. Powder $\mathrm{X}$-ray diffraction data were obtained on a Shimadzu XRD 7000S diffractometer ( $\mathrm{Cu} \mathrm{K} \alpha$ radiation). The following parameters were used: $2 \theta$ step $=0.03^{\circ}$, counting time $=1.0-2.5 \mathrm{~s}, 2 \theta$ scan range $=3-30^{\circ}$. For compounds 2-6, the powder X-ray diffraction patterns are present in Figures S7-11, ESI. Fourier-transform infrared (FTIR) spectra in the range from $4000-300 \mathrm{~cm}^{-1}$ were measured on a Vertex 80 spectrometer. The IR spectra are present in Figure S17, Supplementary Information. Thermogravimetric analyses (TGA) were obtained on a NETZSCH TG 209 F1. The sample quantity ranged from 2 to $10 \mathrm{mg}$. All samples were heated under helium atmosphere from room temperature up to $550{ }^{\circ} \mathrm{C}$ at a $10{ }^{\circ} \mathrm{C} \cdot \mathrm{min}^{-1}$ heating rate. Elemental $\mathrm{C}, \mathrm{H}, \mathrm{N}$ analysis data for 2-6 were obtained on a Eurovector 600 analyzer. The excitation and emission spectra of the solid samples were recorded on a fluorescence spectrophotometer Cary Eclipse (Varian). The emission spectra of the complexes were recorded at room temperature under the following experimental conditions: $\lambda_{\mathrm{ex}}=300$ and $420 \mathrm{~nm}, V=500 \mathrm{~V}$, spectral slit width $=1.8-5 \mathrm{~mm}$. The photoluminescent $(\mathrm{PL})$ spectra were registered for the samples prepared by grinding compounds to powder between two quartz glasses. The thin layer of powder between glasses was placed at $45^{\circ}$ to the excitation light beam. The xenon flash lamp was used as a light source to excite the steady-state PL spectra. ${ }^{1} \mathrm{H}$ NMR spectra were recorded on a Bruker Advance 500 spectrometer and referenced to residual protons of DMF-d7 solvent. The atomic absorption spectroscopy data were collected using AA spectrophotometer Z-8000 (AAS analysis) for 2, 4, 5 and 6 compounds to define $\mathrm{Li}: \mathrm{Zn}, \mathrm{Li}: \mathrm{Co}$ ratios. Samples were dissolved in acidified water.

\section{Synthetic procedures.}

Synthesis of $\left[\mathrm{Li}_{2} \mathrm{CO}_{2}(\text { piv })_{6}(\text { py })_{2}\right]$ (1). A mixture of $\left[\mathrm{Co}(\text { piv })_{2}\right]_{\mathrm{n}}(0.30$ $\mathrm{g}, 1.15 \mathrm{mmol}$ ) and Lipiv $(0.124 \mathrm{~g}, 1.15 \mathrm{mmol})$ was dissolved in a mixture of $\mathrm{CH}_{3} \mathrm{CN}(30 \mathrm{~mL})$ and THF $(10 \mathrm{~mL})$. The reaction mixture after addition of pyridine $(0.111 \mathrm{~mL}, 1.38 \mathrm{mmol})$ was refluxed and heated at $50^{\circ} \mathrm{C}$ for $60 \mathrm{~min}$. The resulting blue colour solution was filtered and evaporated up to $20 \mathrm{~mL}$ volume and cooled to room temperature. THF $(5 \mathrm{~mL})$ was added to a blue solution and kept at room temperature for 24 hours. Formed blue crystals (suitable for X-ray diffraction) were separated from the solution by decantation, washed with cold $\mathrm{CH}_{3} \mathrm{CN}\left(5^{\circ} \mathrm{C}\right)$, and dried in air. The yield of compound 1 was $0.310 \mathrm{~g}$ (60\%). Anal (\%). Found: $\mathrm{C}, 53.5 ; \mathrm{H}, 7.25 ; \mathrm{N}, 3.15$. Calculated for $\mathrm{C}_{40} \mathrm{H}_{64} \mathrm{Co}_{2} \mathrm{Li}_{2} \mathrm{~N}_{2} \mathrm{O}_{12}: \mathrm{C}, 53.6 ; \mathrm{H}, 7.2 ; \mathrm{N}, 3.1$. IR $\left(\mathrm{cm}^{-}\right.$ 1): 2960 m, 2924 w, 2902 w, 2969 w, 1603 s, 1577 s, 1563 s, 1482 s, 1457 m, 1447 s, $1419 \mathrm{~s}, 1403 \mathrm{~s}, 1378 \mathrm{~s}, 1358 \mathrm{~s}, 1218 \mathrm{~s}$, 1153 w, 1070 m, 1043 m, 1030 w, 1015 v.w, 938 v.w, 893 m, 793 m, 754 m, 695 s, 678 v.w, 639 m, 613 s, 574 m, 551 w, 434 s.

Synthesis of $\left[\mathrm{Li}_{2} \mathrm{Zn}_{2}(\mathbf{p i v})_{6}(\mathbf{p y})_{2}\right]$. Heterometallic complex was obtained according to previously published technique [32].

Synthesis of [LiCo(btc)(dma) $\left.)_{2}\right] \cdot 2 \mathrm{DMA}$ (2). $\left[\mathrm{Li}_{2} \mathrm{Co}_{2}(\text { piv })_{6}(\mathrm{py})_{2}\right] \quad(25$ $\mathrm{mg}, 0.03 \mathrm{mmol}$ ) was dissolved in $2 \mathrm{~mL}$ of DMA. Then $2 \mathrm{~mL}$ of $\mathrm{H}_{3}$ btc $(25 \mathrm{mg}, 0.12 \mathrm{mmol}$ ) DMA solution was added. The resultant mixture was sealed in a glass tube and heated up to $100^{\circ} \mathrm{C}\left(1^{\circ} \mathrm{C} / \mathrm{min}\right)$ and kept at $100^{\circ} \mathrm{C}$ for 24 hours. Violet transparent crystals were filtered off and dried in air (yield 25 $\mathrm{mg}, 0.04 \mathrm{mmol}, 69 \%$ based on the starting complex). Anal (\%). Found: $\mathrm{C}, 48.3 ; \mathrm{H}, 6.6 ; \mathrm{N}, 9.0$. Calculated for $\mathrm{C}_{25} \mathrm{H}_{39} \mathrm{CoLiN}_{4} \mathrm{O}_{10}$ : C, 48.3; H, 6.3; N, 9.0. IR ( KBr, cm $\left.{ }^{-1}\right): 1629 \mathrm{~s}, 1598 \mathrm{~s}, 1509 \mathrm{~m}$, $1442 \mathrm{~s}, 1411 \mathrm{~s}, 1349 \mathrm{~s}, 1260 \mathrm{~m}, 1185 \mathrm{~m}, 1091 \mathrm{w}, 1038 \mathrm{~m}, 1016$ m, 941 w, 807 w, 771 s, 749 w, 709 s, 594 m, 563 w, 482 m. Li:Co ratio found $1.08: 1$.

Synthesis of [ $\left.\mathrm{LiZn}(\mathrm{btc})(\mathrm{dma})_{2}\right] \cdot \mathrm{DMA}(3) \cdot\left[\mathrm{Li}_{2} \mathrm{Zn}_{2}(\text { piv })_{6}(\mathrm{py})_{2}\right](2 \mathrm{mg}$, $0.002 \mathrm{mmol}$ ) was dissolved in $1 \mathrm{~mL}$ of DMA. Then $0.5 \mathrm{~mL}$ of $\mathrm{H}_{3}$ btc $(2 \mathrm{mg}, 0.008 \mathrm{mmol}$ ) DMA solution was added. The resultant mixture was sealed in a glass tube and heated up to $100^{\circ} \mathrm{C}\left(1^{\circ} \mathrm{C} / \mathrm{min}\right)$ and kept at $100^{\circ} \mathrm{C}$ for 24 hours. A couple of colourless transparent crystals suitable for X-ray diffraction were obtained.

Synthesis of $\left[\operatorname{LiZn}(\mathrm{btc})(\mathrm{dmf})_{2}\left(\mathrm{H}_{2} \mathrm{O}\right)_{2}\right] \cdot 0.5 D M F \quad(4 \mathrm{dmf})$. [ $\left.\mathrm{Li}_{2} \mathrm{Zn}_{2}(\text { piv })_{6}(\text { py })_{2}\right](25 \mathrm{mg}, 0.03 \mathrm{mmol})$ was dissolved in $2 \mathrm{~mL}$ of DMF. Then $2 \mathrm{~mL}$ of $\mathrm{H}_{3}$ btc ( $25 \mathrm{mg}, 0.12 \mathrm{mmol}$ ) DMF solution was added. The resultant mixture was sealed in a glass tube and heated up to $100^{\circ} \mathrm{C}\left(1^{\circ} \mathrm{C} / \mathrm{min}\right)$ and kept at $100^{\circ} \mathrm{C}$ for 24 hours. Colourless transparent crystals were filtered off and dried in air (yield $18 \mathrm{mg}, 0.037 \mathrm{mmol}, 62 \%$ based on the starting complex). Anal (\%). Found: C, 39.5; H, 4.9; N, 7.3. Calculated for $\mathrm{C}_{16.5} \mathrm{H}_{24.5} \mathrm{LiN}_{2.5} \mathrm{O}_{10.5} \mathrm{Zn}$ : C, 39.8; $\mathrm{H}, 4.9 ; \mathrm{N}, 7.0$. IR $\left(\mathrm{KBr}, \mathrm{cm}^{-1}\right)$ : $1664 \mathrm{~s}, 1620 \mathrm{~s}, 1576 \mathrm{~m}, 1491 \mathrm{w}, 1433 \mathrm{~s}, 1354 \mathrm{~s}$, 1247 w, 1091 m, 1056 w, 931 w, 776 s, 722 s, 665 m, 554 w, $474 \mathrm{w}$. Li:Zn ratio found $1.09: 1$.

Synthesis of $\left[\mathrm{LiZn}(\mathrm{btc})(\mathrm{dma})_{2}\left(\mathrm{H}_{2} \mathrm{O}\right)_{2}\right] \cdot \mathrm{H}_{2} \mathrm{O}(\mathbf{4 d m a})$. The method of synthesis was similar to that for $\mathbf{4} \mathbf{d m f}$ but in DMA solvent instead of DMF. Colourless transparent crystals were filtered off and dried in air (yield $21 \mathrm{mg}, 0.042 \mathrm{mmol}, 70 \%$ based on the starting complex). Anal (\%). Found: $\mathrm{C}, 40.4 ; \mathrm{H}, 5.2 ; \mathrm{N}, 5.5$. Calculated for $\mathrm{C}_{17} \mathrm{H}_{27} \mathrm{LiN}_{2} \mathrm{O}_{11} \mathrm{Zn}$ : C, 40.2; $\mathrm{H}, 5.3 ; \mathrm{N}, 5.5$. IR $(\mathrm{KBr}$, $\mathrm{cm}^{-1}$ ): $1642 \mathrm{~s}, 1575 \mathrm{~m}, 1500 \mathrm{w}, 1438 \mathrm{~s}, 1358 \mathrm{~s}, 1251 \mathrm{w}, 1096$ m, 1047 w, 1011 w, 936 w, 771 s, 718 s, 665 m, 558 w, 465 w. Li:Zn ratio found $1.12: 1$.

Synthesis of $\left[\operatorname{LiZn}(b t c)(n m p)_{2}\left(\mathrm{H}_{2} \mathrm{O}\right)_{2}\right] \cdot 2 \mathrm{NMP}(4 \mathrm{nmp})$. The method of synthesis was similar to that for $\mathbf{4 d m f}$ but in NMP solvent instead of DMF. Colourless transparent crystals were filtered 
off and dried in air (yield $25 \mathrm{mg}, 0.036 \mathrm{mmol}, 60 \%$ based on the starting complex). Anal (\%). Found: $\mathrm{C}, 48.3 ; \mathrm{H}, 6.3 ; \mathrm{N}, 7.8$. Calculated for $\mathrm{C}_{29} \mathrm{H}_{43} \mathrm{LiN}_{4} \mathrm{O}_{12} \mathrm{Zn}$ : C, 48.9; $\mathrm{H}, 6.1 ; \mathrm{N}$, 7.8. IR $(\mathrm{KBr}$, $\mathrm{cm}^{-1}$ ): $1642 \mathrm{~s}, 1589 \mathrm{~m}, 1504 \mathrm{~m}, 1438 \mathrm{~s}, 1353 \mathrm{~s}, 1300 \mathrm{~m}, 1260$ w, 1167 w, $1100 \mathrm{~m}, 980 \mathrm{w}, 936 \mathrm{w}, 776 \mathrm{~s}, 722 \mathrm{~s}, 656 \mathrm{~m}, 576 \mathrm{w}$, $469 \mathrm{~m}$. Li:Zn ratio found $1.10: 1$.

Synthesis of [LiCo(btb)(dmf $\left.)_{2}\right] \cdot 2 \mathrm{DMF}(5 \mathrm{dmf}) \cdot\left[\mathrm{Li}_{2} \mathrm{Co}_{2}(\mathrm{piv})_{6}(\mathrm{py})_{2}\right]$ (25 mg, $0.03 \mathrm{mmol}$ ) was dissolved in $2 \mathrm{~mL}$ of DMF and $4 \mathrm{~mL}$ of $\mathrm{CH}_{3} \mathrm{CN}$ were added. Then $2 \mathrm{~mL}$ of $\mathrm{H}_{3} \mathrm{btb}(53 \mathrm{mg}, 0.12 \mathrm{mmol})$ DMF solution was added. The resultant mixture was sealed in a glass tube and heated up to $100^{\circ} \mathrm{C}\left(1^{\circ} \mathrm{C} / \mathrm{min}\right)$ and kept at $100^{\circ} \mathrm{C}$ for 24 hours. Big violet transparent crystals were filtered off and dried in air (yield $30 \mathrm{mg}, 0.038 \mathrm{mmol}, 65 \%$ based on the starting complex). Anal (\%). Found: $\mathrm{C}, 58.3 ; \mathrm{H}, 5.9 ; \mathrm{N}, 6.9$. Calculated for $\mathrm{C}_{39} \mathrm{H}_{43} \mathrm{CoLiN}_{4} \mathrm{O}_{10}$ : C, 59.0; $\mathrm{H}, 5.5 ; \mathrm{N}, 7.0$. IR $(\mathrm{KBr}$, $\mathrm{cm}^{-1}$ ): $1664 \mathrm{~s}, 1602 \mathrm{~s}, 1522 \mathrm{~s}, 1389 \mathrm{~s}, 1251 \mathrm{w}, 1180 \mathrm{w}, 1100 \mathrm{w}$, $1003 \mathrm{~m}, 851 \mathrm{~m}, 785$ s, $709 \mathrm{w}, 660 \mathrm{w}, 469 \mathrm{~m}$. Li:Co ratio found $1.14: 1$.

Synthesis of [ LiCo(btb)(dma) 2]-2DMA (5dma). The method of synthesis was similar to that for $\mathbf{5 d m f}$ but in DMA solvent instead of DMF. Big violet transparent crystals were filtered off and dried in air (yield $36 \mathrm{mg}, 0.042 \mathrm{mmol}, 72 \%$ based on the starting complex). Anal (\%). Found: $\mathrm{C}, 60.3 ; \mathrm{H}, 5.9 ; \mathrm{N}, 6.6$. Calculated for $\mathrm{C}_{43} \mathrm{H}_{51} \mathrm{CoLiN}_{4} \mathrm{O}_{10}$ : C, 60.8; $\mathrm{H}, 6.0 ; \mathrm{N}, 6.6$. IR (KBr, $\mathrm{cm}^{-1}$ ): $1620 \mathrm{~s}, 1593 \mathrm{~s}, 1553 \mathrm{w}, 1504 \mathrm{w}, 1380 \mathrm{~s}, 1261 \mathrm{w}, 1176 \mathrm{w}$, 1140 w, 1096 w, 1012 m, 865 m, 803 w, 785 s, 701 w, 665 w, $580 \mathrm{w}, 482 \mathrm{~m}$. Li:Co ratio found $1.12: 1$.

Synthesis of $\left[\operatorname{LiZn}(\mathrm{btb})(\mathrm{dmf})_{2}\right] \cdot 2 \mathrm{DMF} \cdot \mathrm{H}_{2} \mathrm{O}(6 \mathrm{dmf})$. The method of synthesis was similar to that for $\mathbf{5 d m f}$ but with $\left[\mathrm{Li}_{2} \mathrm{Zn}_{2}(\text { piv })_{6}(\mathrm{py})_{2}\right]$ as starting complex. Colourless transparent crystals were filtered off and dried in air (yield $36 \mathrm{mg}, 0.044$ $\mathrm{mmol}, 75 \%$ based on the starting complex). Anal (\%). Found: $\mathrm{C}$, 56.8; H, 5.3; N, 6.4. Calculated for $\mathrm{C}_{39} \mathrm{H}_{45} \mathrm{LiN}_{4} \mathrm{O}_{11} \mathrm{Zn}: \mathrm{C}, 57.2 ; \mathrm{H}$, 5.5; N, 6.8. IR $\left(\mathrm{KBr}, \mathrm{cm}^{-1}\right): 1651 \mathrm{~s}, 1593 \mathrm{~s}, 1549 \mathrm{~m}, 1496 \mathrm{w}$, $1442 \mathrm{~m}, 1385 \mathrm{~s}, 1251 \mathrm{~m}, 1180 \mathrm{~m}, 1135 \mathrm{w}, 1096 \mathrm{~m}, 1056 \mathrm{w}$, 1011 w, 860 m, 807 w, 780 s, 713 w, 665 m, 563 w, 496 m. Li:Zn ratio found $1.11: 1$.

Synthesis of $\left[\operatorname{LiZn}(\mathrm{btb})(\mathrm{dma})_{2}\right] \cdot 2 \mathrm{DMA}(6 \mathrm{dma})$. The method of synthesis was similar to that for $\mathbf{5} \mathbf{d m a}$ but in DMA solvent instead of DMF and with $\left[\mathrm{Li}_{2} \mathrm{Zn}_{2}(\text { piv })_{6}(\mathrm{py})_{2}\right]$ as starting complex. Colourless transparent crystals were filtered off and dried in air (yield $34 \mathrm{mg}, 0.041 \mathrm{mmol}, 68 \%$ based on the starting complex). Anal (\%). Found: C, 60.0; H, 5.9; N, 6.6. Calculated for $\mathrm{C}_{43} \mathrm{H}_{51} \mathrm{LiN}_{4} \mathrm{O}_{10} \mathrm{Zn}: \mathrm{C}, 60.3 ; \mathrm{H}, 6.0 ; \mathrm{N}, 6.5$. IR $\left(\mathrm{KBr}, \mathrm{cm}^{-1}\right): 1660$ s, $1584 \mathrm{~s}, 1558 \mathrm{~m}, 1500 \mathrm{w}, 1438 \mathrm{~m}, 1380 \mathrm{~s}, 1251 \mathrm{~m}, 1176 \mathrm{w}$, $1140 \mathrm{w}, 1100 \mathrm{~m}, 1060 \mathrm{w}, 1016 \mathrm{~m}, 856 \mathrm{~m}, 807 \mathrm{w}, 785 \mathrm{~s}, 709 \mathrm{w}$, $665 \mathrm{~m}, 482 \mathrm{~m}$. Li:Zn ratio found $1.08: 1$.

Guest exchange and synthesis of $\left[\mathrm{LiZn}(\mathrm{btc})\left(\mathrm{H}_{2} \mathrm{O}\right)_{4}\right] \cdot \mathrm{C}_{6} \mathrm{H}_{5} \mathrm{NO}_{2}$ (4dmf-NB), [LiZn(btc) $\left.\left(\mathrm{H}_{2} \mathrm{O}\right)_{4}\right] \cdot \mathrm{C}_{8} \mathrm{H}_{9} \mathrm{NO}_{2} \quad$ (4dmf-NX) and

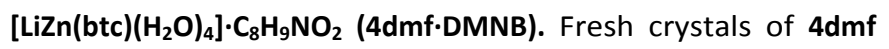
were soaked in the correspondent guest solution (NB nitrobenzene, NX - 4-nitro-m-xylene, DMNB - 2,6dimethylnitrobenzene) ( $1 \mathrm{~mL}$ ) for 48 hours, then filtered and dried in air. Anal (\%). Found for 4dmf.NB: C, 37.1; H, 3.3; N, 2.5. Calculated for $\mathrm{C}_{15} \mathrm{H}_{16} \mathrm{LiNO}_{12} \mathrm{Zn}: \mathrm{C}, 37.9 ; \mathrm{H}, 3.4 ; \mathrm{N}, 2.9$.
Found for 4dmf-NX: C, 38.3; H, 3.5; N, 3.2. Calculated for $\mathrm{C}_{17} \mathrm{H}_{20} \mathrm{LiNO}_{12} \mathrm{Zn}: \mathrm{C}, 40.6 ; \mathrm{H}, 4.0 ; \mathrm{N}, 2.8$. Found for 4dmf.DMNB: C, 40.2; H, 3.5; N, 3.7. Calculated for $\mathrm{C}_{17} \mathrm{H}_{20} \mathrm{LiNO}_{12} \mathrm{Zn}$ : C, 40.6; $\mathrm{H}, 4.0 ; \mathrm{N}, 2.8$.

Guest exchange and synthesis of $\left[\operatorname{LiZn}(b t b)(d m f)_{2}\right] \cdot 2 \mathrm{C}_{6} \mathrm{H}_{5} \mathrm{NO}_{2}$ (6dmf.NB), [LiZn(btb)(dmf) $\left.{ }_{2}\right] \cdot 2 \mathrm{C}_{8} \mathrm{H}_{9} \mathrm{NO}_{2} \cdot \mathrm{H}_{2} \mathrm{O} \quad$ (6dmf.NX) and [LiZn(btb)(dmf) $)_{2} \cdot 2 \mathrm{C}_{8} \mathrm{H}_{9} \mathrm{NO}_{2}$ (6dmf-DMNB). Fresh crystals of $6 \mathrm{dmf}$ were soaked in the correspondent guest solution (NB nitrobenzene, NX - 4-nitro-m-xylene, DMNB - 2,6dimethylnitrobenzene) ( $1 \mathrm{~mL}$ ) for 48 hours, then filtered and dried in air. Anal (\%). Found for 6dmf-NB: C, 59.6; $\mathrm{H}, 4.5 ; \mathrm{N}$, 6.5. Calculated for $\mathrm{C}_{45} \mathrm{H}_{39} \mathrm{LiN}_{4} \mathrm{O}_{12} \mathrm{Zn}: \mathrm{C}, 60.0 ; \mathrm{H}, 4.4 ; \mathrm{N}, 6.2$. Found for 6dmf-NX: C, 61.7; $\mathrm{H}, 5.1 ; \mathrm{N}, 5.8$. Calculated for $\mathrm{C}_{49} \mathrm{H}_{47} \mathrm{LiN}_{4} \mathrm{O}_{12} \mathrm{Zn}: \mathrm{C}, 61.5 ; \mathrm{H}, 5.0 ; \mathrm{N}, 5.8$. Found for 6dmf.DMNB: C, 59.5; $\mathrm{H}, 5.2 ; \mathrm{N}, 5.7$. Calculated for $\mathrm{C}_{49} \mathrm{H}_{49} \mathrm{LiN}_{4} \mathrm{O}_{13} \mathrm{Zn}$ : C, 60.4; $\mathrm{H}, 5.1 ; \mathrm{N}, 5.7$.

\section{X-ray crystallography.}

The X-ray diffraction study of complex $\mathbf{1}$ was carried out on an Enraf Nonius CAD-4 diffractometer (graphitemonochromatized Mo-K $\alpha$ radiation, $\lambda=0.71073 \AA$ ) at $293 \mathrm{~K}$ according to a standard technique [56]. Semi-empirical absorption corrections were applied [57]. The structure was solved by direct methods and by Fourier techniques and was refined by the full-matrix least squares method against $F^{2}$ with anisotropic thermal parameters for all non-hydrogen atoms. The hydrogen atoms of the carbon-containing ligands in the compounds were positioned geometrically and refined using the riding model. All calculations were carried out with the use of the SHELX97 and SHELXL-2013 software packages [58]. Diffraction data for single crystals of $\mathbf{2 , 3}, \mathbf{5 d m a}$ and $\mathbf{6 d m f}$ were obtained at $130 \mathrm{~K}$ on an automated Agilent Xcalibur diffractometer equipped with a two-dimensional AtlasS2 detector (graphite monochromator, $\lambda($ MoK $\alpha)=0.71073 \AA$ A). Integration, absorption correction, and determination of unit cell parameters were performed using the CrysAlisPro program package [59]. The structures of all compounds were solved by a direct method and refined by the full-matrix least squares technique in the anisotropic approximation (except hydrogen atoms) using the SHELX-2014 software [57]. Positions of hydrogen atoms of organic ligands were calculated geometrically and refined in the riding model. The crystallographic data and details of the structure refinements are summarized in Table 1. CCDC 1883246-1883250 contain the supplementary crystallographic data for this paper. These data can be obtained free of charge from The Cambridge Crystallographic Data Center at http://www.ccdc.cam.ac.uk/data request/cif.

\section{Surface Area and Porous Structure.}

An analysis of the porous structure was performed by a nitrogen adsorption technique using Quantochrome's Autosorb iQ at $77 \mathrm{~K}$. Initially the compounds $\mathbf{5}$ and $\mathbf{6}$ were first activated in dynamic vacuum $\left(10^{-8} \mathrm{bar}\right)$ at $70^{\circ} \mathrm{C}$ during $6 \mathrm{~h}$ after guest exchange with acetone for $48 \mathrm{~h}$. The nitrogen sorption on activated sample $\mathbf{2}$ was studied on a dynamic SORBTOMETER-M instrument by 5 -point method in relative 
pressures range $0.05-0.25$. The sample was activated under $\mathrm{N}_{2}$ stream at $100^{\circ} \mathrm{C}$ for $30 \mathrm{~min}$.

$\mathrm{N}_{2}$ adsorption-desorption isotherms were measured within the range of relative pressures of $10^{-6}$ to 0.995 . The specific surface area was calculated from the data obtained on the basis of the conventional BET, Langmuir and DFT models. Pore size distributions were calculated using DFT.

$\mathrm{N}_{2}, \mathrm{CO}_{2}$ and $\mathrm{CH}_{4}$ Sorption Experiments at 273 and $298 \mathrm{~K}$. Gases adsorption isotherm measurements were carried out volumetrically on Quantochrome's Autosorb iQ equipped with thermostat TERMEX M01 to adjust temperature with $0.1 \mathrm{~K}$ accuracy. Adsorption-desorption isotherms were measured within the range of pressures of 1 to 800 torr. The database of the National Institute of Standards and Technology Thermophysical Properties of Fluid Systems, Database of National Institute of Standards and Technology, NIST. http://webbook.nist.gov/chemistry/fluid/] was used as a source of $\mathrm{p}-\mathrm{V}-\mathrm{T}$ relations at experimental pressures and temperatures.

\section{Conclusions}

Substitution of pivalate ligands in $\left[\mathrm{Li}_{2} \mathrm{M}_{2}(\text { piv })_{6}(\mathrm{py})_{2}\right]$ (where $\left.\mathrm{M}=\mathrm{Zn}^{2+}, \mathrm{Co}^{2+}\right)$ with tricarboxylate bridges $\left(\mathrm{btc}^{3-}, \mathrm{btb}^{3-}\right)$ affords two general structural types of coordination polymers: $3 \mathrm{D}$ frameworks with chiral $\mathrm{SrSi}_{2}$ topology when the carboxylate group plane towards the plane of benzene ring in btc ${ }^{3-}$ lies in the same plane or 2D honeycomb structures in case of btb $b^{3-}$ linker when the angle between the central benzene ring and the plane of COO- group is close to $90^{\circ}$. In both cases binuclear $\left\{\mathrm{LiM}(\mathrm{RCOO})_{3}\right\}$ 3-connected nodes preserve their structure during the ligand substitution demonstrating a rare example of rational step-by-step MOF structure design from preorganized heterometallic complexes. The obtained layered Zn-containing coordination polymers are capable of a guest-dependent luminescent behavior with drastic changes in luminescence intensity and quantum yields on nitroaromatics inclusion. Moreover, a rare example of permanent porosity and fine selectivity in both cases of $\mathrm{CO}_{2} / \mathrm{N}_{2}$ and $\mathrm{CO}_{2} / \mathrm{CH}_{4}$ separation for layered compounds was found.

\section{Conflicts of interest}

There are no conflicts to declare.

\section{Acknowledgements}

The work was supported by RFBR (grant No. 17-53-16015)

\section{Notes and references}

1 K. Sumida, D. L. Rogow, J. A. Mason, T. M. McDonald, E. D. Bloch, Z. R. Herm, T.-H. Bae and J. R. Long, Chem. Rev., 2012, 112, 724.

2 Z. Zhang, Z.-Z. Yao, S. Xiang and B. Chen, Energ. Envir. Sci., 2014, 7, 2868.
3 J. Sculley, D. Yuan and H.-C. Zhou, Energ. Environ. Sci., 2011, 4, 2721.

4 M. P. Suh, H. J. Park, T. K. Prasad and D.-W. Lim, Chem. Rev., 2012, 112, 782.

5 Y. He, W. Zhou, G. Qian and B. Chen, Chem. Soc. Rev., 2014, 43, 5657.

6 J.-R. Li, J. Sculley and H.-C. Zhou, Chem. Rev., 2012, 112, 869.

7 B. Van de Voorde, B. Bueken, J. Denayer and D. De Vos, Chem. Soc. Rev., 2014, 43, 5766.

8 Y. Liu, W. Xuan and Y. Cui, Adv. Mater., 2010, 22, 4112.

9 M. P. Yutkin, D. N. Dybtsev and V. P. Fedin, Russ. Chem. Rev., 2011, 80, 1009.

10 J. Liu, L. Chen, H. Cui, J. Zhang, L. Zhang and C.-Y. Su, Chem. Soc. Rev., 2014, 43, 6011.

11 M. Yoon, R. Srirambalaji and K. Kim, Chem. Rev., 2012, 112, 1196.

12 Z. Hu, B.J. Deibert and J. Li, Chem. Soc. Rev., 2014, 43, 5815.

13 K. Müller-Buschbaum, F. Beuerle and C. Feldmann, Micropor. Mesopor. Mat., 2015, 216, 171.

14 C. Wang, T. Zhang and W. Lin, Chem. Rev., 2012, 112, 1084.

15 P. Horcajada, R. Gref, T. Baati, P.K. Allan, G. Maurin, P. Couvreur, G. Férey, R.E. Morris and C. Serre, Chem. Rev., 2012, 112, 1232

16 A. Pichon and S. L. James, Cryst. Eng. Comm., 2008, 10, 1839.

17 Z.-Q. Li, L.-G. Qiu , T. Xu, Y. Wu, W. Wang, Z.-Y. Wu and X. Jiang, Mater. Lett., 2009, 63, 78.

18 S. Hausdorf, F. Baitalow, T. Bohle, D. Rafaja and F. O. R. L. Mertens, J. Am. Chem. Soc., 2010, 132, 10978.

19 A. S. Munch, M. S. Lohse, S. Hausdorf, G. Schreiber, D. Zacher, R. A. Fischer and F. O. R. L. Mertens, Micropor. Mesopor. Mat., 2012, 159, 132.

20 R. Nayuk, D. Zacher, R. Schweins, C. Wiktor, R. A. Fischer, G. van Tendeloo and K. Huber, J. Phys. Chem. C, 2012, 116, 6127.

21 D. Zacher, R. Nayuk, R. Schweins, R. A. Fischer and K. Huber, Cryst. Growth Des., 2014, 14, 4859.

22 D. Prochowicz, K. Sokołowski, I. Justyniak, A. Kornowicz, D. Fairen-Jimenez, T.Friščić and J. Lewiński, Chem. Commun., 2015, 51, 4032.

23 V. Guillerm, S. Gross, C. Serre, T. Devic, M. Bauerc and G. Férey, Chem. Commun., 2010, 46, 767.

24 K. Užarević, T. C. Wang, S.-Y. Moon, A. M. Fidelli, J. T. Hupp, O. K. Farha and T. Friščić, Chem. Commun., 2016, 52, 2133.

25 C. Serre, F. Millange, S. Surblé and G. Férey, Angew. Chem. Int. Ed., 2004, 43, 6285.

26 S. Surblé, C. Serre, C. Mellot-Draznieks, F. Millange and G. Férey, Chem. Commun., 2006, 0, 284.

27 S. Surblé, F. Millange, C. Serre, G. Férey and R. I. Walton, Chem. Commun., 2006, 0, 1518.

28 S. Wongsakulphasatch, F. Nouar, J. Rodriguez, L. Scott, C. Le Guillouzer, T. Devic, P. Horcajada, J.-M. Grenèche, P. L. Llewellyn, A. Vimont, G. Clet, M. Daturid and C. Serre, Chem. Commun., 2015, 51, 10194.

29 D. N. Dybtsev, A. A. Sapianik and V. P. Fedin, Mendeleev Commun., 2017, 27, 321.

30 E. M. Cheprakova, E. V. Verbitskiy, M. A. Kiskin, G. G. Aleksandrov, P. A. Slepukhin, A. A. Sidorov, D. V. Starichenko, Y. N. Shvachko, I. L. Eremenko, G. L. Rusinov and V. N. Charushin, Polyhedron, 2015, 100, 89.

31 Z. V. Dobrohotova, A. A. Sidorov, M. A. Kiskin, K. S. Gavrichev, A. V. Turin, A. L. Emelina, M. A. Bykov, A. S. Bogomyakov, I. P. Markelova, A. S. Alihanian, V. M. Novotortsev and I. L. Eremenko, J. Solid State Chem., 2010, 183, 2475

32 A. A. Sapianik, E. N. Zorina-Tikhonova, M. A. Kiskin, D. G. Samsonenko, K. A. Kovalenko, A. A. Sidorov, I. L. Eremenko, D. N. Dybtsev, A. J. Blake, S. P. Argent, M. Schroder, V. P. Fedin, Inorg. Chem., 2017, 56, 1599-1608. 
33 Y.-P. Li, X.-X. Wang, S.-N. Li, H.-M. Sun, Y.-C. Jiang, M.-C. Hu, Q.-G. Zhai, Cryst. Growth Des., 2017, 17, 5634.

34 A.L. Spek, Acta Crystallogr. D, 2009, 65, 148.

35 O. M. Yaghi, C. E. Davis, G. Li and H. Li, J. Am. Chem. Soc., 1997, 119, 2861

36 S. R. Caskey and A. J. Matzger, Inorg. Chem., 2008, 47, 7942.

37 M. Oh, L. Rajput, D. Kim, D. Moon and M. Soo Lah, Inorg. Chem., 2013, 52, 3891.

38 X. Huang, Y. Chen, Z. Lin, X. Ren, Y. Song, Z. Xu, X. Dong, X. Li, C. Hu and B. Wang, Chem. Commun., 2014, 50, 2624

39 A.L. Spek, Acta Crystallogr. C, 2015, 71, 9.

40 A. A. Sapianik, M. A. Kiskin, D. G. Samsonenko, A. A. Ryadun, D. N. Dybtsev and V. P. Fedin, Polyhedron, 2018, 145, 147.

41 O. M. Yaghi, M. O'Keeffe, N. W. Ockwig, H. K. Chae, M. Eddaoudi and J. Kim, Nature, 2003, 423, 705.

42 E. V. Alexandrov, V. A. Blatov, A. V. Kochetkov and D. M. Proserpio, CrystEngComm, 2011, 13, 3947.

43 Y. X. Bai, J. W. Qian, Q. Zhao, Y. Xu and S. R. Ye, J. Appl. Polym. Sci., 2006, 102, 2832.

44 S. Mukherjee, B. Manna, A. V. Desai, Y. Yin, R. Krishna, R. Babarao and S. K. Ghosh, Chem. Commun., 2016, 52, 8215.

45 S. Shimomura, S. Horike, R. Matsuda and S. Kitagawa, J. Am. Chem. Soc., 2007, 129, 10990.

46 A. M. Cheplakova, K. A. Kovalenko, D. G. Samsonenko, V. A. Lazarenko, V. N. Khrustalev, A. S. Vinogradov, V. M. Karpov, V. E. Platonov and V.P. Fedin, Dalton Trans., 2018, 47, 3283.

47 I. A. Ibarra, T. W. Hesterberg, J.-S. Chang, J. W. Yoon, B. J. Holliday and S. M. Humphrey, Chem. Commun., 2013, 49, 7156.
48 M. A. Braverman, R. M. Supkowski and R. L. LaDuca, J. Solid State Chem., 2007, 180, 1852.

49 J. He, J.-X. Zhang, G.-P. Tan, Y.-G. Yin, D. Zhang and M.-H. Hu, Cryst. Growth Des., 2007, 7, 1508.

50 T. K. Koltunova, D. G. Samsonenko, M. I. Rakhmanova, D. N. Dybtsev and V. P. Fedin, Russ. Chem. Bull., 2015, 64, 2903.

51 H. Wang, W. Yang and Z.-M. Sun, Chem. Asian J., 2013, 8, 982.

52 S. B. Aliev, D. G. Samsonenko, M. I. Rakhmanova, D. N. Dybtsev and V. P. Fedin, Cryst. Growth Des., 2014, 14, 4355.

53 H. Xiang, W.-Y. Gao, D.-C. Zhong, L. Jiang and T.-B. Lu CrystEngComm, 2011, 13, 5825.

54 Z. Dobrokhotova, A. Emelina, A. Sidorov, G. Aleksandrov, M. Kiskin, P. Koroteev, M. Bykov, M. Fazylbekov, A. Bogomyakov, V. Novotortsev and I. Eremenko, Polyhedron, 2011, 30, 132.

55 I. G. Fomina, G. G. Aleksandrov, Zh. V. Dobrokhotova, O. Yu. Proshenkina, M. A. Kiskin, Yu. A. Velikodnyi, V. N. Ikorskii, V. M. Novotortsev and I. L. Eremenko, Russ. Chem. Bull., 2006, 55, 1909.

56 K. Harms, XCAD4 - Program for the Lp-Correction of Nonius CAD4 DATA, Marburg, 1997

57 G.M. Sheldrick, SADABS, Program for Scaling and Correction of Area Detector Data, Göttingen University, Göttinngen, Germany, 1997

58 G. M. Shedrick, Acta Crystallogr. A, 2008, 64, 112.

59 CrysAlisPro 1.171.38.41. Rigaku Oxford Diffraction. 2015. 
Table 1. Crystal data and structure refinement for 1, 2, 3, 5 and 6

\begin{tabular}{|c|c|c|c|c|c|}
\hline Identification code & 1 & 2 & 3 & $5 \mathrm{dma}$ & $6 \mathrm{dmf}$ \\
\hline Empirical formula & $\mathrm{C}_{40} \mathrm{H}_{64} \mathrm{Li}_{2} \mathrm{~N}_{2} \mathrm{O}_{12} \mathrm{Co}_{2}$ & $\mathrm{C}_{25} \mathrm{H}_{39} \mathrm{CoLiN}_{4} \mathrm{O}_{10}$ & $\mathrm{C}_{21} \mathrm{H}_{30} \mathrm{LiN}_{3} \mathrm{O}_{9} \mathrm{Zn}$ & $\mathrm{C}_{39} \mathrm{H}_{42} \mathrm{CoLiN}_{3} \mathrm{O}_{9}$ & $\mathrm{C}_{36} \mathrm{H}_{36} \mathrm{LiN}_{3} \mathrm{O}_{9} \mathrm{Zn}$ \\
\hline$M, \mathrm{~g} / \mathrm{mol}$ & 896.67 & 621.47 & 540.79 & 762.62 & 726.99 \\
\hline $\mathrm{T}, \mathrm{K}$ & 293 & 130 & 130 & 130 & 130 \\
\hline Crystal system & Triclinic & Tetragonal & Tetragonal & Monoclinic & Monoclinic \\
\hline Space group & $P-1$ & $P 4_{3} 2_{1} 2$ & $P 4_{1} 2_{1} 2$ & $12 / a$ & $12 / a$ \\
\hline$a, \AA$ & $9.379(3)$ & $13.1202(2)$ & $13.2635(3)$ & $11.2469(4)$ & $11.8491(5)$ \\
\hline$b, \AA$ & $12.106(5)$ & $13.1202(2)$ & $13.2635(3)$ & 29.1732(9) & $29.0049(10)$ \\
\hline$c, \AA$ & $12.656(5)$ & $17.6987(4)$ & $17.6166(4)$ & $12.3612(4)$ & $12.2371(4)$ \\
\hline$\alpha$, deg. & $117.147(10)$ & 90 & 90 & 90 & 90 \\
\hline$\beta$, deg. & $96.610(10)$ & 90 & 90 & $92.248(3)$ & $93.249(3)$ \\
\hline$\gamma$, deg. & $89.912(10)$ & 90 & 90 & 90 & 90 \\
\hline$V, \AA^{3}$ & $1268.0(8)$ & $3046.65(12)$ & $3099.12(17)$ & $4052.7(2)$ & $4198.9(3)$ \\
\hline$z$ & 1 & 4 & 4 & 4 & 4 \\
\hline$D\left(\right.$ calcd), $\mathrm{g} / \mathrm{cm}^{3}$ & 1.174 & 1.355 & 1.159 & 1.250 & 1.150 \\
\hline$\mu, \mathrm{mm}^{-1}$ & 0.706 & 0.621 & 0.836 & 0.478 & 0.634 \\
\hline$F(000)$ & 474 & 1308 & 1128 & 1596 & 1512 \\
\hline Crystal size, $\mathrm{mm}$ & $0.43 \times 0.23 \times 0.12$ & $0.20 \times 0.20 \times 0.18$ & $0.33 \times 0.28 \times 0.22$ & $0.38 \times 0.17 \times 0.11$ & $0.23 \times 0.21 \times 0.15$ \\
\hline $\begin{array}{l}\theta \text { range for data } \\
\text { collection, deg. }\end{array}$ & $1.89-24.41$ & $3.31-26.37$ & $3.44-29.45$ & $3.58-29.50$ & $3.44-25.35$ \\
\hline Index ranges & $\begin{array}{c}0 \leq h \leq 9 \\
-14 \leq k \leq 14 \\
-14 \leq l \leq 14\end{array}$ & $\begin{array}{c}-14 \leq h \leq 12 \\
-16 \leq k \leq 11 \\
-22 \leq l \leq 13\end{array}$ & $\begin{array}{c}-17 \leq h \leq 17 \\
-11 \leq k \leq 16 \\
-24 \leq l \leq 22\end{array}$ & $\begin{array}{c}-14 \leq h \leq 15 \\
-34 \leq k \leq 36 \\
-14 \leq l \leq 15\end{array}$ & $\begin{array}{c}-14 \leq h \leq 14 \\
-34 \leq k \leq 28 \\
-14 \leq l \leq 11\end{array}$ \\
\hline $\begin{array}{l}\text { Reflections collected / } \\
\text { independent }\end{array}$ & 4744 / 4015 & 8033 / 3093 & 10902 / 3696 & 10599 / 4784 & 9055 / 3838 \\
\hline$R_{\text {int }}$ & 0.0539 & 0.0198 & 0.0272 & 0.0186 & 0.0220 \\
\hline $\begin{array}{l}\text { Reflections with } I> \\
2 \sigma(I)\end{array}$ & 3027 & 2907 & 3266 & 3780 & 3040 \\
\hline Goodness-of-fit on $F^{2}$ & 1.110 & 1.092 & 1.133 & 1.053 & 1.061 \\
\hline $\begin{array}{l}\text { Final } R \text { indices }[I> \\
2 \sigma(I)]\end{array}$ & $\begin{array}{c}R_{1}=0.0718 \\
w R_{2}=0.1910\end{array}$ & $\begin{array}{c}R_{1}=0.0359 \\
w R_{2}=0.0824\end{array}$ & $\begin{array}{c}R_{1}=0.0637 \\
w R_{2}=0.1849\end{array}$ & $\begin{array}{c}R_{1}=0.0782 \\
w R_{2}=0.2430\end{array}$ & $\begin{array}{c}R_{1}=0.0657 \\
w R_{2}=0.2063\end{array}$ \\
\hline$R$ indices (all data) & $\begin{array}{c}R_{1}=0.0944, \\
w R_{2}=0.2109\end{array}$ & $\begin{array}{c}R_{1}=0.0398 \\
w R_{2}=0.0842\end{array}$ & $\begin{array}{c}R_{1}=0.0712 \\
w R_{2}=0.1951\end{array}$ & $\begin{array}{c}R_{1}=0.0934 \\
w R_{2}=0.2578\end{array}$ & $\begin{array}{c}R_{1}=0.0795 \\
w R_{2}=0.2180\end{array}$ \\
\hline $\begin{array}{c}\text { Largest diff. peak / } \\
\text { hole, } e / \AA^{3}\end{array}$ & $0.500 /-0.798$ & $0.375 /-0.156$ & $0.851 /-0.405$ & $0.875 /-0.804$ & $0.645 /-0.509$ \\
\hline
\end{tabular}

